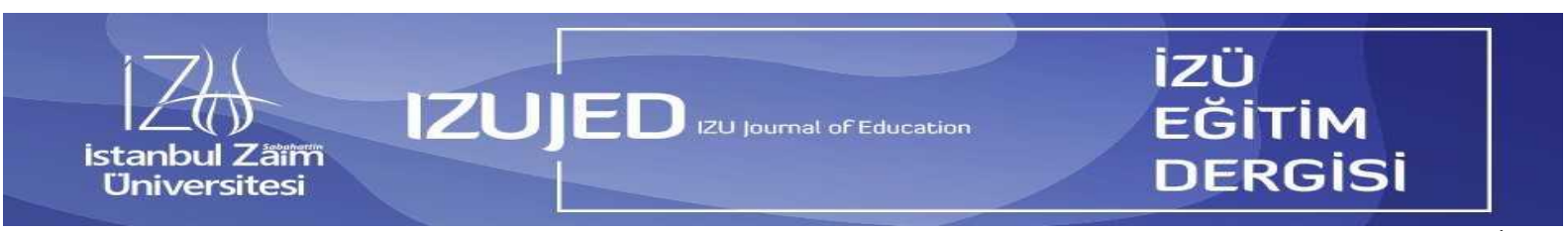

Başvuru: 23 Aralık 2020

Copyright (C) 2019 İZU

Kabul: 29 Kasim 2021

DOI: $10.46423 /$ izujed.841318

Cilt 3 (2021) Say1 6 98-127

http://dergipark.gov.tr/izujed

\title{
Öğretmenlerin Öz Yeterlilikleri ile Sınıf Yönetimi Becerileri ve Arasındaki İlişkinin İncelenmesi
}

\author{
Hatice VATANSEVER BAYRAKTAR ${ }^{1}$
}

Oğuz ÇELIK ${ }^{2}$

Öz

Bu araştırmanın amacı öğretmenlerinin özyeterlilikleri ile sınıf yönetimi becerilerinin ne düzeyde olduğu; öğretmenlerin özyeterlilikleri ve sınıf yönetimi becerilerinin cinsiyet, eğitim düzeyi, bulunduğu okuldaki toplam hizmet süresi, mesleki kıdem, branş ve alınan hizmetiçi eğitim değişkenlerine göre anlamlı düzeyde farklılık gösterip göstermediği ve öğretmenlerin öz yeterlilikleri ile sınıf yönetimi becerileri arasında istaitistiksel olarak anlamlı bir ilişkinin olup olmadığını incelemektir. Araştırmada betimsel tarama modeli kullanılmıştır. Araştırmanın evreni, İstanbul ili Güngören, Bağcılar ve Bahçelievler ilçesinde yer alan ilkokul ve ortaokul öğretmenlerinden oluşmaktadır. Örneklem ise evrenden rastgele yöntemle seçilen toplam 394 öğretmenden (171 ilkokul ve 223 ortaokul öğretmeni) oluşmaktadır. Araştırmada "Kişisel Bilgiler Formu", "Öğretmen Öz-yeterlik Ölçeği" ile "Sınıf Yönetimi Becerileri Ölçeği" kullanılmıştır. Verilerin analizi sonucunda öğretmenlerin sınıf yönetimi becerilerinin cinsiyet, okuldaki toplam hizmet süresi ve branş değişkenlerine göre istatistiksel olarak anlamlı bir farklılık gösterdiği tespit edilmiştir. Öğretmenlerin sınıf yönetimi becerileri eğitim düzeyi, mesleki kıdem ve alınan hizmetiçi eğitim değişkenlerine göre anlamlı bir farklılık göstermemektedir. Öğretmenlerin özyeterlikleri eğitim düzeyi, mesleki kıdem, branş ve alınan hizmet içi eğitim değişkenlerine göre anlamlı bir farklılık göstermektedir. Öğretmenlerin özyeterlikleri cinsiyet, bulunduğu okuldaki toplam hizmet süresi değişkenlerine göre anlamlı bir farklılık göstermemektedir. Öğretmenlerin özyeterlilikleri ile sınıf yönetimi becerileri arasında pozitif yönlü ve orta düzeyli ilişki olduğu tespit edilmiştir.

Anahtar Kelimeler: Özyeterlilik, Sınıf, Sınıf Yönetimi.

\section{Investigation of the Relationship Between Teachers' Self-Efficacy and Classroom Management Skills}

\begin{abstract}
"Bu çalışma, Oğuz Çelik'in, Doç. Dr. Hatice VATANSEVER BAYRAKTAR danışmanlığında İstanbul Sabahattin Zaim Üniversitesi Sosyal Bilimler Enstitüsünde yaptığı lisansüstü tezin bir bölümünden üretilmiştir.

${ }^{1}$ Sorumlu Yazar: Doç. Dr., İstanbul Sabahattin Zaim Üniversitesi, Eğitim Fakültesi, İstanbul, Turkey, Email: hatice.bayraktar@izu.edu.tr

ORCID: 0000-0002-0458-3405
\end{abstract}

Abstract

The aim of this study is to determine the level of teachers' self-efficacy and classroom management skills; Whether teachers' self-efficacy and classroom management skills differ significantly according to gender, education level, Total service time at the school, professional seniority, subject-matter and inservice training and to examine whether there is a statistically significant relationship between teachers' self-efficacy and classroom management skills. Descriptive survey model was used in the research. The population of the research consists of primary and secondary school teachers located in the districts of

2 Milli Eğitim Bakanlığı, İstanbul, Türkiye, mail: oguzcelik89@hotmail.com

ORCID: 0000-0002-0118-1822

Atıf: Vatansever-Bayraktar, H. \& Çelik, O. (2021). Öğretmenlerin Öz Yeterlilikleri ile Sınıf Yönetimi Becerileri Arasındaki İlişkinin İncelenmesi. İZÜ Ĕ̆itim Dergisi, 3(6) 98-127.

DOI: 10.46423 izujed.841318 
Güngören, Bağcllar and Bahçelievler in Istanbul. The sample consists of a total of 394 teachers (171 primary school and 223 secondary school teachers) randomly selected from the universe. "Personal Information Form", "Teacher Self-Efficacy Scale" and "Classroom Management Skills Scale" were used in the study. As a result of the data analysis, it was determined that the classroom management skills of the teachers showed a statistically significant difference according to the variables of gender, total service time in school and subject-matter. Teachers' classroom management skills do not differ significantly according to education level, professional seniority and in-service training variables. Teachers' self-efficacy differ significantly according to the variables of education level, professional seniority, subject-matter and in-service training received. Teachers' self-efficacy does not differ significantly according to the variables of gender, the total service time in the school where the school is located. It has been determined that there is a positive and medium level relationship between teachers' self-efficacy and classroom management skills.

Keywords: Self-efficacy, Classroom, Classroom Management.

\section{Extended Abstract Introduction}

Self-efficacy is one of the key concepts of Social Learning Theory. It is an individual's selfperception of his ability to organize and implement the required practices to achieve performance. In other words, it is an individual's judgment about whether he can do a job. Self-efficacy is an individual's perception of his ability to deal with the situations they face and achieve a particular job. It has a significant impact on the motivation and confidence of individuals. Individuals strive to perform a task or to achieve learning by intrinsic motivation without the need for external intervention. For example, students' perception of their selfefficacy for a chemistry topic, in addition to techniques used and classroom environment when teaching that topic, will have an impact on their learning level. In this context, a psychological approach, along with the environmental impact is important to achieve success (Senemoglu, 2005: 58).

Studies conducted on teachers' self-efficacy belief suggest that their self-efficacy belief has a significant impact on the teaching style, classroom behavior, being open to new ideas, developing new teaching attitudes (Ashton, 1984; Gibson \& Dembo, 1984; Ramey \& Shroyer, 1992 as cited by Vatansever Bayraktar, 2016). If today's education system trains teachers with high self-efficacy, it may contribute to achieving the desired success (Akbas \& Celikaleli, 2006: 27). It is believed that teachers with high self-efficacy can enhance student motivation and help them improve their success levels taking into account student needs and adopting a studentcentered approach (Ashton \& Webb, 1986; Tsachannen-Moran et al., 2002 as cited by Vatansever Bayraktar, 2016).

The classroom is the smallest unit where learning takes place. A classroom can be described as the environment where students and teachers come together (Cakmak, 2005: 24). Classroom management is where students and teachers share their thoughts comfortably, students are at the center of learning, and teachers take on the guidance task to have students achieve their goals. In the past, class management was considered equivalent to discipline. Whereas, most researchers argue that class management and discipline are not the same; classroom management is more than just preventing and controlling student misconduct (Yasar, 2008: 9). Beginner teachers spend most of their energy to control students and the classroom (Demirtas, 2011: 13).

\section{Objective}


The overall objective of the research is to investigate the relationship between teachers' selfefficacy and classroom management skills. As part of this overall objective, answers to the following questions will be sought:

1) Does teachers' self-efficacy and classroom management skills differ significantly according to gender, education level, total service time at the school, professional seniority, subject-matter and in-service training?

2) Is there a relationship between teachers' self-efficacy and classroom management skills?

\section{Method}

\section{Research Design}

The study was conducted using a quantitative research technique, namely the descriptive survey model. The survey model can be described as "research conducted usually on a relatively larger sample than other research to determine participants' views, or characteristics e.g. interest, skills, attitudes toward a topic or phenomenon" (Karasar, 2015:122). Therefore, the correlational survey method was used in this study.

\section{Population and Sample}

The research population consists of primary and secondary school teachers working at Gungoren, Bagcilar and Bahcelievler Districts of Istanbul Province. The sample consists of 171 Primary and 224 Secondary School teachers randomly selected from the population.

\section{Data Collection Instruments}

In the research, data on teachers' perception of self-efficacy was collected by the "Teacher SelfEfficacy Scale" developed by Tschannen-Moran and Hoy (2001), and adapted to Turkish by Çapa, Çakıroğlu and Sarıkaya (2005).

Data on their classroom management skills were collected by a scale developed by Delson in 1982 and adapted to Turkish by Yalçınkaya and Tonbul in 2002. The scale consists of one dimension and 25 questions.

\section{Findings and Discussion}

As a result of the analyses under the research subproblems, female teachers were found to have a higher level of classroom management skills than male teachers. However, it was also seen to vary based on the teachers' educational level. Accordingly, the level of self-efficacy of teachers with an associate degree in relation to student involvement and the level of their overall self-efficacy was seen to be higher than that of teachers with an undergraduate degree.

Another analysis suggested some variations in views on self-efficacy and classroom management in relation to their professional length of service. The findings suggest that teachers working at the school for 11-15 years have a higher level of classroom management than teachers working for less than a year.

The analysis of the research's main problem, i.e., the relationship between the views on selfefficacy and classroom management, suggests that their self-efficacy level and classroom management level have a linear relationship. This suggests that teachers' classroom management level will increase as their self-efficacy level increases. 
The research investigated whether teachers' classroom management skill level and selfefficacy belief level varied significantly by gender variable. It was reported that classroom management skill level of teachers participating in the research varied significantly by gender variable in favor of female teachers, and however, that their self-efficacy belief did not vary by gender variable. There are studies available in the literature that are and are not in parallel with the findings derived about teachers' classroom management skills and self-efficacy in relation to gender. There are several studies discovering that gender is a determining factor in classroom management skills (Güner, 2010; İlgar, 2007; Uslu \& Avc1, 2016; Yalçınkaya \& Tonbul, 2002). The results of a study by Vatansever-Bayraktar and Kendirci (2020) suggest that primary school teachers' classroom management skills vary statistically significantly by gender variable in favor of female primary school teachers in the general total and in learningteaching process, communication, behavior management sub-dimensions. This research result also supports the present research.

However, it suggests that gender is not a determining factor in self-efficacy belief (Aksoy, 2000; Aldan-Karademir, 2013; Benzer, 2011; Buluç ve Demir (2015); Hashemi ve Ghanizadeh, 2011; Saracaloğlu \& Aydoğdu, 2012; Şahin-Taşkın ve Hacıömeroğlu, 2010; Urhan, 2013; Uysal, 2013; Uysal \& Kösemen, 2013; Yorgancı \& Bozgeyikli, 2016, Ekici, 2008). For example, Güneş (2021) did not find any significant variation between gender and classroom management skills of teachers. A review of the sub-dimensions suggests that female teachers are more effective than male teachers in one of the key elements of classroom management i.e., managing the behaviors within the classroom and using time effectively. If we look at the results in terms of self-efficacy belief, while there was no significant variation between the total self-efficacy belief and gender, male teachers were found to be more effective than female teachers in ensuring student involvement in the class. Hashemi and Ghanizadeh (2011) did not find any significant variation between self-efficacy and gender. The study by Aldan Karademir (2013) suggests that there is no significant variation between total self-efficacy belief and gender, but there is a significant variation only in the classroom management sub-dimension.

\section{Recommendations}

- The studies in the literature appear to have used quantitative research methods mostly. There may be different studies adopting qualitative research methods on classroom management skills and self-efficacy belief.

- This study was conducted on primary and secondary school teachers in Istanbul. Results derived from applications on subject field and primary school teachers in schools at different levels in different provinces and on results derived from applications on academics at higher education schools can be compared with teachers at different levels.

- Administrators can improve the quality of education by ensuring that teachers improve their classroom management skills through self-efficacy improvement training, seminars etc.

- Teachers can be informed by experts in classroom management skills.

- The MoNE central and district organizations must provide additional support to teachers working at regions and schools that are likely to weaken self-efficacy belief. 


\section{Giriş}

Öz yeterlik, Sosyal Öğrenme Kuramının önemli kavramlarındandır. Bireyin bir performansı gerçekleştirmek için gerekli uygulamaları düzenleyip yerine getirme kapasitesi ile ilgili kendine ilişkin algısıdır. Bir başka deyişle bireylerin bir işi yapabileceği yönündeki yargısıdır. Öz yeterlik, bireylerin karşılaştıkları durumlarla baş edebilme, belli bir işi başarma kapasitesine ilişkin algısıdır. Bireylerin motivasyonunu ve özgüvenini önemli ölçüde etkiler. İlgili dersin konusu işlenirken kullanılan teknikler ve sınıf ortamının yanısıra öğrencilerin konuya ilişkin öz yeterlik algıları da öğrenme düzeyi üzerinde etkili olur (Senemoğlu, 2005: $58)$.

Birey, bir görevi yerine getirebilecek kapasiteye sahip olduğu halde kendine olan inanc1 yetersiz ise bu konuda başarısız olabilir. Öz yeterlik algısı, yapılacak işlerde karşılaşılabilecek zorluklara karşı gösterilen direnci ve çabayı da belirlemektedir. Öz yeterlik inancı yüksek olan bireyler başarıya inanırlar ve bunu gerçekleştirene kadar denemeye devam ederler. Başarı odaklı çalışırlar, yeteneklerine inanırlar, cesaretlidirler ve kendilerine güvenirler. Karşılaştıkları sorunlar karşısında üstün çaba harcarlar ve kolayca yılmazlar. Bunun aksine öz yeterlik inancı düşük olan bireyler başarısızlık kaygısı ile çabuk vazgeçerler. Sorunlarla baş etmekte zorluk çekerler, problem çözme konusunda başarısız olurlar, öz güven eksikliği yaşarlar, yeteneklerine ve bilgilerine şüphe ile yaklaşırlar (Pajares, 2002: 68).

Bireyler eylemlerinin sonuçlarına ilişkin farklı düşüncelere sahiptir. Düşündükleri bir işle ilgili harekete geçmeden önce sonuçlarla birlikte yapabileceklerine yönelik inançlarını da göz önünde bulundururlar. Dolayısı ile eğitim süreci için düşünülecek olursa öğretmenlerin kendilerine yönelik inançları öğrenci başarısı açısından önemlidir. Öz yeterlik algısı düşük ve kendini yetersiz hisseden öğretmenlerin inançlarını arttırmaya yönelik çalışmalar yapılmalıdır. Aksi takdirde öğrencilerin akademik başarıları ve tutumları bu durumdan olumsuz yönde etkilenebilmektedir (Bandura, 1988: 75).

Birey gelişiminde yeterlik bireyin kendini gerçekleştirebilmesi için oldukça önemlidir (Schriver ve Czerniak, 1999: 23). Yeterlik kavramından bahsedildiği zaman akla ilk gelen isim Bandura'dır. Yeterlik inancı çerçevesinde birey kendini ne kadar yeterli görürse o kadar aktif rol alacak ve bir o kadar fazla çaba harcayacaktır (Ritter, Boone ve Rubba, 2001: 175).

Öz yeterlik "insanların kendi hayatını etkileyen olayları kontrol etme yeterliklerine yönelik görüşleri" dir (Bandura, 1977: 194). Öz-yeterliliğin geniş tanımı, bir etki üretme gücü olarak ifade edilebilir (Lacour ve Wilkerson, 1991 akt. Vatansever Bayraktar, 2016). Bandura (1988)'nın sosyal öğrenme kuramının temel kavramlarında biridir. Bandura'ya göre öz yeterliğe sahip birey kendi kapasitesine olan inancını fark eder. Öz yeterliği düşük olan öğretmenlerin güçlükler karşısında pasif ve çekingen kaldıkları, çözüm üretmekten kaçındıkları görülmüştür. Zorluk anında gösterdikleri çaba minimum düzeyde kalmıştır. Kendilerine özgüvenleri olmadıklarından yeterli performans gösteremezler, sorumluluk almaktan kaçınır, bir görev üstlenmekten kaçınırlar. Düşük öz yeterliğe sahip öğretmenler başarısız öğrencileri sınıfta bırakma eğilimi taşır ve onu geliştirmek için hiç sorumluluk almazlar. Buna karşın öz yeterliği yüksek olan öğretmenler ise düşük başarıya sahip öğrencileri başarabilir ve çözümlenebilir olarak değerlendirir, onları geliştirmek adına her türlü sorumluluğu almayı göze alabilirler. Öğrencilerine derslerinde çağdaş yöntemler kullanır ve bunlar için onları teşvik edici olurlar. Zorluklar karşısında en üst düzeyde çaba 
gösterip çözüm üretebilirler. Verilen görevlere odaklanabilir ve bu görevin üstesinden gelebilirler (Bandura, 1988: 79).

Öğretmenlerin öz yeterlikleri ile ilgili yapılan çalışmalar sonucunda öz yeterliği yüksek olan öğretmenlerin öğretim yöntemlerini kullanma konusunda daha yeterli daha istekli oldukları görülmüştür (Ashton, 1984: 29). Öğretmenlerin öz yeterlik inancı yetiştirecekleri öğrencileri de her alanda etkileyebileceği ve onları iyi bir şekilde eğitip, yönlendireceği göz önünde bulundurulduğunda öğretmenlerin öz yeterlik inançlarına oldukça fazla önem verilmesi gerektiği görülmektedir (Roberts, vd. 2001: 199). Öğretmenin sahip olduğu öz yeterlik inanc1 ile kullanmış olduğu yöntem ve teknikleri, sınıf içerisinde yapmış olduğu çalışmaları, öğrencilerin derse katılmasını ve öğrencilerin anlatılanları anlamasını oldukça fazla etkilemekte bu da öğrencinin başarısını etkilemektedir (Akbaş ve Çelikkaleli, 2006: 25). Öz yeterliği yüksek olan öğretmenler geleneksel yöntemler kullanmak yerine çağdaş eğitim yöntemlerini kullanmayı tercih ederken, öz yeterlik düzeyi düşük olan öğretmenler öğretmen merkezli yaklaşımları kullanmayı tercih eder (Ashton, 1984: 30). Öğretmenlerin öz-yeterlik inançları üzerine yapılan çalışmalar öğretmenlerin öz-yeterlik inançlarının, öğretim tarzı, sınıf davranışları, yeni fikirlere açık olmaları, yeni öğretim tutumlarının geliştirilmesi üzerinde önemli bir etkiye sahip olduğunu göstermektedir (Ashton, 1984; Gibson ve Dembo, 1984; Ramey ve Shroyer, 1992' den akt. Vatansever Bayraktar, 2016). Günümüz eğitim sisteminde öz yeterliği yüksek öğretmenler yetiştirilirse istenilen başarının sağlanmasına katkı sağlamış olunabilinir (Akbaş ve Çelikkaleli, 2006: 27). Öz-yeterlik inancı yüksek öğretmenlerin, öğrencilerin motivasyonunu arttırabileceğine ve öğrencilerin ihtiyaçlarının göz önüne alınarak ve öğrenci merkezli bir yaklaşım benimseyerek başarı düzeylerini yükseltmelerine yardımcı olabileceğine inanılmaktadır (Tschannen-Moran ve diğerleri, 2002'den akt. Vatansever Bayraktar, 2016).

Öğretmenin sahip olduğu becerilerilerle öğrencide öğrenmeye karşı istenen sonuçları oluşturabilmesine ilişkin (Tschannen-Moran, Hoy ve Hoy, 1998: 207) inancı onun öz yeterlik düzeyini ortaya koyacaktır (Goddard, Hoy ve Woolfolk-Hoy, 2004: 8). Nitekim, öz yeterlik inancı ile ilgili yapılan araştırmalar, öğretmenlerin mesleki yeteneklerine olan inançlarının öğretmen davranışlarını ve öğrenci başarısını etkileyebildiğini göstermektedir (Ashton, 1984: 8; Çapa, Çakıroğlu ve Sarıkaya, 2005: 80; Ross ve Bruce, 2007: 57).

Öz yeterlik algısı yüksek olan öğretmenlerin öğrenci merkezli yaklaşımlarla araştırmaya dayalı öğrenme yaklaşımlarını sıklıkla kullandıkları ve bunda başarılı oldukları gözlemlenmiştir. Ne var ki öz yeterlik düzeyi düşük olan öğretmenlerin öğretmen merkezli yaklaşıma dayalı öğretim verdikleri görülmüş̧ür (Schriver, 1993: 76). Ayrıca öz yeterlik inancı yüksek olan öğretmenlerin sınıf içi öğretime daha çok vakit ayırdıkları, öğrencilerin ihtiyaçlarına daha duyarlı olmakla birlikte öğrencilere karşı pozitif ve kabul edici bir tutum sergiledikleri söylenebilmektedir (Ashton, 1984: 9).

Özyeterlik inançlarının, bilişsel sistem içerisinde anahtar bir motive edici rolü bulunmaktadır. Bandura, özyeterlik algısının, insan davranışlarının ve davranış değişikliklerinin temel belirleyicilerinden biri olduğunu öne sürmektedir. Özyeterlik algısı arttıkça, gösterilen çaba, kararlılık ve azim de artmaktadır. Öte yandan, özyeterlik algısı düşük olan bireylerin zor görevlerden kaçındıkları, zorluklar karşısında hemen pes ettikleri ve daha çok endişeyle daha düşük performans gösterip daha başarısız oldukları gözlenmektedir (Pajares, 2002: 64). 
Birçok çalışmada öğrenci katılımına yönelik öz-yeterlik ile öğrencilerin başarı düzeyleri arasındaki ilişki araştırılmıştır. Dolayısıyla, bu boyut en etkili faktörlerden biri olarak görülmektedir. Öğrencinin dikkatini çekme ve sürdürme becerisi öğrenci katılımı olarak tanımlanır. Ayrıca boyuta ulaşmak için gerekli üç öğrenci katılım türü vardır. Bunlar (Conner, 2016: 13):

- Davranış yoluyla katılım: Bu boyut öğrencinin olumlu davranışını, öğrenmeye ve etkinliklere katılımını içerir. Bu nedenle, bu boyut öğrencinin okul ortamıyla etkileşim kurma şeklini değerlendirir.

- Duygularla etkileşim: Bu boyut, olumlu ya da olumsuz bir duygu olmasına bakılmaksızın, öğrencinin öğretmenin davranışını algılama biçimi ve duygusal bir tavırla bu davranışa verdiği tepkiyi ifade eder.

- Bilişsel katılım: Bu boyut öğrencilerin yönergelerle etkinlik yapma biçimini değerlendirir.

Öğretim stratejilerine yönelik öz-yeterlik, öğretmen ve öğrenci arasındaki davranış ve ilişkinin analiz yoluyla yorumlanma şeklidir. Bu nedenle, birçok ilke tanımlanmıştır (Shinn, 1997: 23):

- Öğretmen ve öğrenciler arasında deneyim paylaşımı.

- Sınıf ortamında eleştirel düşünceyi başkalarına aktarma.

- $\quad$ Öğrenme süreci.

- Bilgiyi analiz etme ve başkalarına iletme becerisi.

- Gerçek hayatta olan durumları değerlendirmek için eleştirel düşünme becerileri.

- Şahsen veya donanım kullanarak bilgi dağıtma.

- Öğrencilerin kendi potansiyellerini aşmak için onlara gerekli rehberliği ve dürtüyü sağlama yeteneği.

- Öğrenme ve keşfetme konusundaki ilgisini artırın.

Öğrencilerin akademik performanslarıyla öğretim stratejileri ve yöntemleri arasında da bir ilişki vardır. Ganyaupfu (2013) tarafından yapılan araştırmada üç öğretim yöntemi araştırılmıştır: öğretmen odaklı, öğrenci odaklı ve etkileşimli bir yöntem. Araştırma sonucunda öğrenci performanslarının üç öğretim yöntemi arasında anlamlı olarak farklılaştığını ve bu üç yöntem içeresinde etkileşimli öğretim yönteminin en yüksek puana sahip olduğu görülmüştür.

Sınıf yönetimine yönelik öz-yeterlik; öğretmenin sınıf ortamında verimli ve sosyal açıdan kabul edilebilir bir davranış ortamı geliştirme kabiliyeti olarak tanımlanır. Alanyazında etkin sınıf yönetimi sağlamada öğretmenlere yardımcı olabilecek bazı stratejiler sunulmuştur. Bunlar (Ganyaupfu, 2013: 30):

- Dersler için bir rutinin belirlenmesi.

- Kuralları ve bu kurallara uymamanın sonuçlarını tanımlama.

- Bütün öğrencilere adil davranılması.

- Kesintileri en aza indirme.

- Mizahın kontrollü bir şekilde kullanılabileceği rahat bir sınıf iklimi oluşturmak. 
- Sınıfın ve her bir öğrenciden bireysel beklentilerini tespit etmektir.

Sınıf yönetimi stratejilerini katılım, ceza, tanınma, saldırganlık, öğretme etkinliği, motivasyon ve akademik başarı gibi farklı değişkenler ile ilişkilendiren bir çalışmanın sonucuna göre olumlu öğretmen sinıf yönetim yeterliği öğrencinin motivasyonunu ve daha sonra öğrencilerin akademik başarılarını artıracaktır (Rahimi ve Karkami, 2015: 57).

Sınıf yönetimi ile birlikte gelen farklı sorunlar vardır. Bu sorunlar dört kategoriye ayrılmıştır: öğrenci merkezli, okul merkezli, müfredat merkezli ve öğretmen merkezli. Öğrenci ile ilgili olanlar, öğrencilerin sınıftaki kurallara aykırı davrandıklarını gösterirken, okulla ilgili olanlar çoğunlukla sınıftaki kuralların uygunluğu ve uygulama biçimiyle ilgilidir. Müfredatla ilgili sorunlar konuların ve yöntemlerin dikkat çekme yeteneği ile ilgilidir. Burada bilgi sunumu ve tartışılması önemli bir rol oynamaktadır. Sonuç olarak, öğretmenle ilgili sorunlar temel olarak öğretmenin sınıf kurallarını belirleme ve bunları öğrencilerle konuşma, öğrencilerin ilgisini ve dikkatini çekme ve bunu muhafaza edebilme konularındaki yetersizlikler sebebiyle ortaya çıkmaktadır (Alzubi, 2013: 140).

Sınıf öğretimin gerçekleştiği en küçük birimdir. Sınıf, öğrenci ve öğretmenin bir araya geldiği, beraber öğrenme yaptıkları ortam olarak tanımlanabilir (Çakmak, 2005: 24). Sınıf yönetimi ilk zamanlarda daha çok katı kuralların yer aldığı, otoritenin tamamen öğretmenin elinde olduğu bir yönetim biçimi olarak ele alınmaktaydı. Fakat günümüzde ise sinıf yönetimi; öğrenci ve öğretmenin düşüncelerini rahatlıkla paylaştıkları, öğrenmenin merkezinde öğrencinin olduğu, öğretmenin görevinin ise öğrencilerine amaçlarına ulaşmak için rehberlik görevini üstlendiği alandır. Eskiden sınıf yönetimi disiplin ile eşdeğer olarak kabul edilirdi. Daha önceleri yapılmış olan sınıf yönetimi araştırmaları öğrencilerin yanlış davranışlarına karşı öğretmenlerin gösterdiği tepkileri araştırmak üzerine yoğunlaşmışlardır. Oysaki çoğu araştırmacı sınıf yönetimi ile disiplinin aynı olmadığını iddia ederler; sınıf yönetimi öğrencilerin yanlış davranışlarını önlemek ve onları kontrol etmekten çok daha öte bir şeydir (Yaşar, 2008: 9).

Sınıf yönetimi 1980'li yılların sonunda eğitim bilimleri disiplinleri içerisinde gelişmiş bir bilim dalıdır. Sınıf yönetiminin çeşitli tanımları vardır. Bu tanımlardan bazıları şu şekildedir: Sınıf yönetimi, sınıf ortamının öğrencilerin eğitimde hedeflenen amaçlarını etkili biçimde gerçekleştirebilecekleri şekilde düzenlenmesini sağlayan ilke ve yöntemlerin bütünüdür (Aydın, 1998). Belirlenen eğitim amaçlarına ulaşabilmek için planlama, örgütleme, uygulama ve değerlendirmeye ilişkin bazı ilke, kavram, kuram, model ve tekniklerden sistematik olarak yararlanılarak yapılan etkinliklerin bütününe sınıf yönetimi denir (Başar, 1999:154).

Sınıf yönetimi; uygun bir sınıf ortamının sağlanabilmesi, sınıf içi kuralların belirlenebilmesi, zamanın ve öğretim sürecinin yönetilebilmesi, öğrenci davranışlarının değerlendirilebilmesi için etkili bir öğretim ikliminin oluşturulabilmesi sürecidir. İnsan kaynağı olarak öğrenci ve öğretmenin, madde kaynağı olarak sınıfta kullanılacak tüm araç-gereç ve sınıf ortamının eğitim öğretim sürecinde elde edilmek istenen amaçlara yönelik doğru ve planlı olarak harekete geçirilebilmesidir (Celep, 2000; Çelik, 2012).

Ülkenin ilerlemesi ve gelişmesi için önemli görevler üstlenen öğretmenlerin etkili bir öğretim yapabilmeleri için etkili bir sınıf yönetimi için gerekli bilgi ve becerilere sahip olması beklenir. Etkili bir sınıf yöneticisi olmak aynı zamanda öğretmenin mutluluğu için çok önemlidir. Sınıf yönetimindeki zorluklar öğretmenin kaygı ve stresiyle ilişkilendirilir. Eğer devam ederse, depresyona ve tükenmişliğe sebep olur. Bunu bilen deneyimler öğretmenler ders yılının 
başlangıcında sınıf yönetimi stratejilerini belirlerken, deneyimsiz öğretmenler öğrencilerin kendilerine saygı duymayacakları endişesi taşırlar (Demirtaş, 2011: 10). Sınıf yönetiminin amacı, öğrenciler için uygun öğrenme etkinlikleri düzenlemek zamanı iyi kullanmak ve hedeflere ulaşmaktır. Sınıf; eğitim örgütleri açısından, amaca ulaşma yolunda, işin "atölye"si olması nedeniyle üzerinde en fazla durulması gereken birimdir.

Öğretmenler, sinıf yönetiminde ve öğrencilerin kendi öğrenmelerinde aktif bir şekilde rol aldığı pozitif öğrenme ortamı yaratırlar. Onlar, fiziksel çevreyi organize eder, öğrenci davranışlarını kontrol eder, güvenliği ve sağlığı düzenler, saygılı bir ortam yaratır, kuralları yumuşatır ve ne zaman ihtiyaç olsa diğer öğretmenlerle iletişime geçerler. Tüm bu konular sınıf yönetimi ile ilgilidir. Asıl hedef pozitif öğrenme ortamı yaratmak, sonra öğrenci davranışlarını yol göstererek ve düzelterek pozitif öğrenme ortamının devamı için adımlar atmaktır. İyi bir sınıf yönetimi oluşturmak için harcadığınız çabanın en değerli özelliği neyi nasıl öğrettiğinizdir çünkü sınıf yönetimi ve eğitim (öğrenim) birbiriyle ilişkilidir. Neyi nasıl öğrettiğiniz, neyi nasıl değerlendirdiğiniz ve sınıfınızı nasıl yönettiğiniz sistemik olarak birbirlerini etkilerler. Eğer bir alanı efektif bir şekilde uygularsanız, diğer ikisi de işe yarar ve pratikte bir alanı yetersiz kullanırsanız diğer ikisi de işe yaramaz. 1997-1998 öğretim yılında öğretmen yetiştiren yükseköğretim kurumlarının programları yeniden düzenlenmiş ve sınıf yönetimi, bu düzenleme çerçevesinde zorunlu bir ders olarak okutulmaya başlanmıştır. Sınıf yönetiminin öğretmen yetiştiren yükseköğretim kurumlarının programlarında yer alması, önemli bir gelişme olarak görülmektedir (Erden, 2003: 30).

Sınıf yönetiminin başarılı olması, okulun unsurlarının kalitesine bağlıdır. Okulun fiziksel koşullarından, bünyesinde çalışan personele ve yöneticilerine kadar tüm unsurları sınıf yönetimini doğrudan ilgilendirir. Bu anlamda sınıf yönetiminin başarısı okulun yönetim ve diğer unsurlarının kalitesine bağlıdır. Okul yönetiminin, bünyesinde bulunan tüm bireylerle olumlu bir hava içerisinde iletişim kurması, onların kişisel gelişimlerine imkân tanıması, öğrencilere, öğretmenlere ve velilere liderlik etmesi, sınıf içerisinde ve okulun tüm alanlarında etkili öğrenme öğretme etkinlikleri gerçekleştirilmesine yönelik tedbirler alması ve bu etkinlikleri desteklemesi gerekmektedir (Özdemir, 2011: 199).

Sınıf yönetimini etkileyen okulla ilgili durumlardan birisi de okul iklimidir. Okul iklimi, öğrencilerin birbirlerine ve öğretmenlerine güven duydukları okul içi ilişkilere ya da öğrenciöğrenci, öğrenci-öğretmen çatışmalarının fazla yaşandığı, güven duygusu barındırmayan okul içi ilişkilere neden olan unsurdur. Okul yöneticisinin ve öğretmenlerin amacı, öğrencilerin rahat ve huzurlu bir ortamda öğrenim görmelerini sağlayacak 1 lımlı bir okul iklimi oluşturmak olmalıdır (Çelik, 2012: 7).

Öğrencilerin cinsiyet, yaş, ilgi, zeka, beklenti, ihtiyaç, motivasyon gibi pek çok özellikleri sınıf yönetimine etki etmektedir. Bu nedenle okul öğrenciye sunduğu eğitim-öğretim hizmetlerini yürütürken onun ihtiyaç duyduğu durumları doğru tespit etmelidir. Eğitim-öğretim hizmetlerinin kalitesini artırmak, ancak öğrenci ihtiyaçlarını tanımakla mümkün olacaktır (Çelik, 2012: 9).

Öğretmenler sınıfta pek çok role sahiptirler. Bu rollerin en önemlilerinden biri şüphesiz sınıf yöneticisi olmalarıdır. Etkili öğretme ve öğrenmenin iyi yönetilemeyen bir sınıfta meydana gelmesi mümkün değildir. Eğer öğrenciler düzensiz ve saygısız ise, belirgin kurallar ve yön gösterici rehber davranışlar yoksa kaos, sınıf düzeni haline gelir. Bu durumdan hem öğrenciler hem de öğretmenler zarar görecektir. Öğretmenler öğretmek için çabalarken, büyük olasılıkla 
öğrenciler, yapabileceklerinden çok daha azını öğreneceklerdir. Bunun tersine iyi yönetilmiş sınıflar, öğretme ve öğrenme durumlarının gelişebileceği bir çevre sağlayacaktır. Fakat iyi bir sınıf yönetimi hiçbir yerde kendiliğinden meydana gelmemektedir. Başarılı bir sınıf yönetiminin meydana gelmesi çok çaba gerektirir ve bunu meydana getirmede en çok sorumluluk sahibi kişi öğretmendir. Sınıf yönetiminin planlama ve düzenleme aşamalarında, öğrenme faaliyetlerinin uygulanmasında en önemli ögelerden biri öğretmendir. Modern çağda eğitim sürecini etkileyen pek çok teknolojik unsur (bilgisayar, internet, telefon vb.) olsa da; öğretmen halen eğitim-öğretim sürecinin en etkin göreve sahip üyesidir (Özdemir, 2011: 202).

Göreve yeni başlayan öğretmenler enerjilerinin çoğunu öğrencileri ve sınıfı kontrol edebilmek için harcamaktadırlar (Demirtaş, 2011: 13). Etkili bir sınıf yöneticisi olmak sonradan kazanılan bir vasıftır. İyi sınıf yöneticileri, bu alanda kullanılan özel teknikleri bilen ve bunları kullanabilen öğretmenlerdir. Öğrencilerine yardım eder, öğütler verir, onları destekler, yaptıkları davranışları onaylar ya da onaylamadığını belirtir. Öğretmen öğrencilerini denetler, yönetir (Demirtaş, 2011: 14).

Konu ile ilgili yapılan çalışmalar incelendiğinde Özer (2013) tarafından yapılan “Aday öğretmenlerin sınıf yönetimi yeterliliklerine ilişkin algıları"; Uç (2013) tarafından yapılan "İlkokul öğretmenlerinin sınıf yönetimi becerileri ile örgüt kültürü arasındaki ilişki"; Martin ve Shoho (2000) tarafından yapılan “Öğretmen deneyimi, eğitimi ve yaş: öğretmen özelliklerinin sınıf yönetim stiline etkisi"; Yaşar (2008) tarafından yapılan "Ilköğretim öğretmenlerinin sınıf yönetimi yaklaşımları"; Vatansever Bayraktar ve Kendirci (2020) tarafından yapılan "Sınıf öğretmenlerinin sınıf yönetimi becerilerinin incelenmesi"; Vatansever Bayraktar ve Doğan (2017) tarafından yapılan "Sınıf öğretmenlerinin sinıf yönetiminde kullandıkları disiplin türlerinin incelenmesi"; Vatansever Bayraktar (2015) tarafından yapılan "Sınıf yönetiminde öğrenci motivasyonu ve motivasyonu etkileyen etmenler"; Penrose, Perry ve Ball (2007) tarafından yapılan “Duygusal zeka ve öğretmen öz yeterliği: öğretmen statüsünün ve deneyim süresinin katkısı"; Baltacı (2008) tarafından yapılan "Ilköğretim okullarında görev yapan yöneticilerin bilgisayar tutumları ile özyeterlilikleri arasındaki ilişkinin incelenmesi"; Yorgancı ve Bozgeyikli (2016) tarafından yapılan "Sınıf öğretmenlerinin kişilerarası özyeterlilik algılarıyla örgütsel güven algılarının incelenmesi"; Yılmaz (2010) tarafından yapılan "Türkçe öğretmen adaylarının özel alan ve öz yeterlik algıları"; Yalçınkaya ve Tombul (2002) tarafından yapılan "İlköğretim okulu sınıf öğretmenlerinin sınıf yönetimi becerilerine ilişkin alg1 ve gözlemler"; Uysal ve Kösemen (2013) tarafından yapılan "Öğretmen adaylarının genel öz yeterlilik inançlarının incelenmesi"; Gündoğan ve Koçak (2017) tarafından "Öğretmen adaylarının okul iklimi algıları ile akademik öz-yeterlik inançları arasındaki ilişkinin incelenmesi"; Kurt (2012) tarafından yapılan “Öğretmenlerin öz yeterlik ve kolektif yeterlik algıları; Koç ve Sak (2016) tarafından yapılan “Okul öncesi öğretmenlerinin okul öncesi eğitim programındaki etkinliklere yönelik özyeterlik inançlarının incelenmesi"; Türk (2009) tarafından yapılan "Beden eğitimi ve spor öğretmenlerinin mesleklerine ilişkin öz yeterlik düzeylerinin incelenmesi (Nevşehir ili örneği)"; Aydın (2020) tarafından yapılan "Sosyal bilgiler öğretmenlerinin mesleki tükenmişlik düzeylerinin ve öğretmen özyeterlik inançlarının incelenmesi"; Bayraktar (2020) tarafından yapılan "Okul yöneticilerinin özyeterlikleri ile politik becerileri arasındaki ilişki", Çolak (2019) tarafından yapılan “Öğretmenlerin özyeterlik algıları ile iş stresleri arasındaki ilişkinin incelenmesi"; Kanık (2019) tarafından yapılan "Sınıf öğretmenlerinin özyeterlik inançları ile mesleğe yönelik tutumlarının karşılaştırılmalı olarak incelenmesi"; Vatansever 
Bayraktar, Kadığlu Ateş ve Afat (2019) tarafından yapılan “Özel yeteneklilerin eğitimine ilişkin sınıf öğretmenlerinin özyeterlik inancı ve tutumu arasındaki ilişkinin incelenmesi; Yaz (2018) tarafından yapılan "Ortaokul öğretmenlerinin özyeterlik algıları ile öğretmen liderliği davranışları arasındaki ilişkinin incelenmesi"; Balcı (2015) tarafından yapılan "Öğretmen ve öğretmen adaylarının eğitim inançları ile özyeterlik inançlarının incelenmesi (Okul öncesi örneği)"; Konan (2018) tarafından yapılan“Kamu ve özel eğitim kurumlarında çalışan ortaöğretim fen bilimleri öğretmenlerinin iş doyumları ve öz yeterlik düzeylerinin çeşitli değişkenler açısından incelenmesi" başlıklı çalışmalara rastlanmıştır. Fakat örneklem grubunu İstanbul'da görev yapan hem ilkokul hem de ortaokul öğretmenlerinin oluşturduğu; öğretmenlerin özyeterlilikleri ile sınıf yönetimi becerilerini birlikte inceleyen bir araştırmaya rastlanmamıştır. Bu bağlamda öğretmenlerin özyeterlilikleri ile sınıf yönetimi becerilerinin çeşitli değişkenlere göre farklılaşıp farklılaşmadığını ve öğretmenlerin özyeterlilikleri ile sınıf yönetimi becerileri arasındaki ilişkiyi inceleyen bu araştırmanın alana katkı sağlayacağı düşünülmektedir.

\section{Araştırmanın Amacı}

Araştırmanın genel amacı öğretmenlerin öz yeterlilikleri ile sınıf yönetimi becerileri arasındaki ilişkinin incelenmesidir. Bu genel amaç çerçevesinde aşağıdaki sorulara yanıt aranacaktır:

1. Öğretmenlerin özyeterlilikleri ve sınıf yönetimi becerileri cinsiyet, eğitim durumu, bulunduğu okuldaki toplam hizmet süresi, mesleki kıdem süresi, branş ve alınan hizmetiçi eğitim değişkenlerine göre istatistiksel olarak anlamlı bir farklılık göstermekte midir?

2. Öğretmenlerin özyeterlilikleri ile sınıf yönetimi becerileri arasında istatistiksel olarak anlamlı bir ilişki var mıdır?

\section{Yöntem}

\section{Araştırmanın Modeli}

Çalışma, gözlemlerin ve ölçme yöntemlerinin tekrarlanabildiği ve sayısal araştırmalar vasıtasıyla gerçekleştirildiği araştırma yöntemi olan nicel araştırma yöntemi kullanılarak gerçekleştirilmiştir. Araştırmada nicel araştırma tekniklerinden olan tarama modeli kullanılmıştır. Tarama araştırmaları "Bir konuya ya da olaya ilişkin katılımcıların görüşlerinin ya da ilgi, beceri, yetenek, tutum vb. özelliklerinin belirlendiği genellikle diğer araştırmalara göre daha büyük örneklemler üzerinde yapılan araştırmalar" şeklinde ifade edilebilir (Karasar, 2015:122). Bu bağlamda çalışmada ilişkisel tarama modeli kullanılmıştır.

\section{Evren ve Örneklem}

Araştırmanın evrenini, İstanbul ilinin Güngören, Bağcılar ve Bahçelievler ilçesinde yer alan ilkokul ve ortaokul öğretmenleri oluşturmaktadır. Örneklem ise evrenden kolay ulaşılabilir durum örneklemesi ile belirlenmiştir. Örneklem İstanbul ilinin Güngören, Bağcclar ve Bahçelievler ilçesinde yer alan ilkokul ve ortaokullarda görev yapan gönüllülük esasına göre seçilen 171 ilkokul ve 223 ortaokul öğretmeni olmak üzere toplam 394 öğretmenden oluşmaktadır. 


\section{Veri Toplama Araçları}

Araştırmada öğretmenlerin öz yeterlilik algıları, Tschannen-Moran ve Hoy (2001) tarafından geliştirilen, Çapa, Çakıroğlu ve Sarıkaya (2005) tarafından Türkçeye uyarlanan "Öğretmen Özyeterlik Ölçeği” ile elde edilmiştir. Ölçek "öğrenci katılımı”, "öğretim stratejileri” ve "sınıf yönetimi" olmak üzere üç alt boyut ve 24 maddeden oluşmaktadır. Araştırmadaki sorular 9'lu Likert tipinde ölçektir. Ölçekler 1 - Yetersiz'den 9 - Çok yeterli şeklinde puanlanmaktadır.

Öğretmenlerin Sınıf Yönetimi Becerileri ise Delson (1982) tarafından geliştirilen, Yalçınkaya ve Tombul (2002) tarafından dilimize uyarlanıp geçerlik ve güvenilirlik çalışması yapılan "Sınıf Yönetimi Becerileri Ölçeği" kullanılarak ölçülmüştür. Tek boyuttan oluşan ölçek 25 sorudan oluşmaktadır. Ölçekteki tüm ifadeler olumlu ifadeleri içermekte olup; 0: gözlenmedi, 1: zayıf, 2: orta, 3: iyi, 4: çok iyi şeklinde karşılık bulmaktadır (Yalçınkaya ve Tonbul, 2002).

\section{Verilerin Analizi ve Güvenilirlik}

Çalışmada elde edilen bulgular değerlendirilirken, istatistiksel analizler için SPSS 22.0 İstatistik paket programı kullanılmıştır. Çalışma verileri değerlendirilirken tanımlayıcı istatistiksel metotları (Frekans, Yüzde, Ortalama, Standart sapma) yönteminden faydalanılmıştır.

Niceliksel verilerin karşılaştırılmasında iki grup durumunda, normal dağılım gösteren parametrelerin gruplar arası karşılaştırmalarında Bağımsız örnekler (Independent samples) t testi, niceliksel verilerin karşılaştırılmasında ikiden fazla grup durumunda, normal dağılım gösteren parametrelerin gruplar arası karşılaştırmalarında Tek yönlü (One way) Anova testi ve farklılığa neden olan grubun tespitinde Tukey testi kullanılmıştır. Ölçekler arasındaki ilişkinin tespit edilmesinde korelasyon analizi uygulanmıştır. Sonuçlar \% 95 güven aralığında, $\mathrm{p}<0,05$ anlamlılık düzeyinde değerlendirilmiştir.

Tablo 1. Güvenilirlik Analizi

\begin{tabular}{lll}
\hline Ölçek & Cronbach's Alpha & Veri Sayısı \\
\hline Özyeterlilik & 0,907 & 24 \\
Sinıf Yönetimi & 0,917 & 25 \\
\hline
\end{tabular}

Tablo 1'e göre araştırmada elde edilen verilerin güvenilirliklerinin test edilmesi için yapılan Cronbach's Alpha testi neticesinde özyeterlilik ölçeğinde yer alan verilerin Cronbach's Alpha test istatistiği 0,907 , sınıf yönetimi ölçeğinde yer alan verilerin Cronbach's Alpha test istatistiği 0,917 olarak tespit edilmiş ve verilerin güvenilir olduğu sonucuna varılmıştır.

\section{Bulgular}

Tablo 2. Öğretmenlerin Özyeterlilik ve Sınıf Yönetim Becerilerine İlişkin Görüşlerinin Cinsiyetlerine Göre Bağımsız Grup t Testi

\begin{tabular}{lllllll}
\hline & Cinsiyet & $\mathrm{N}$ & Ort. & Std. Sapma & $\mathrm{t}$ & $\mathrm{p}$ \\
\hline Özyeterlilik & Kadın & 273 & 7,0183 & 1,09535 & & \\
Öğrenci & Erkek & 121 & 6,9256 & 1,04863 & 0,785 & 0,433 \\
$\begin{array}{l}\text { Katılımı } \\
\text { Özyeterlilik }\end{array}$ & Kadın & 273 & 7,4107 &, 90481 & & \\
$\begin{array}{l}\text { Sını } \\
\text { Yönetimi }\end{array}$ & Erkek & 121 & 7,4225 & 1,01887 & 0,462 & 0,909 \\
& Kadın & 273 & 7,4006 &, 84761 & 0,842 & 0,880 \\
\hline
\end{tabular}




\begin{tabular}{lllllll}
\hline $\begin{array}{l}\text { Özyeterlilik } \\
\text { Öğretim }\end{array}$ & Erkek & 121 & 7,3864 &, 90973 & & \\
$\begin{array}{l}\text { Stratejileri } \\
\text { Genel }\end{array}$ & Kadın & 273 & 7,2766 &, 82480 & 0,699 & 0,732 \\
$\begin{array}{l}\text { Özyeterlilik } \\
\text { Eenel Sinıf }\end{array}$ & Kadın & 121 & 7,2448 &, 89241 & & \\
$\begin{array}{l}\text { Yönetimi } \\
\text { Becerileri }\end{array}$ & Erkek & 121 & 3,4832 &, 35535 & & 0,022 \\
\hline
\end{tabular}

Tablo 2' de araştırmaya katılan öğretmenlerin özyeterlilik ve sınıf yönetim becerilerine ilişkin görüşlerinin cinsiyetlerine göre farklılık analizi Bağımsız grup $t$ testi ile analiz edilmiştir. Yapılan analiz sonucunda kadın öğretmenlerin sınıf yönetim becerileri düzeylerinin erkek öğretmenlere göre daha yüksek düzeyde olduğu tespit edilmiştir $(p<0,05)$.

Öğretmenlerin özyeterlikleri genel olarak ve tüm alt boyutlarda cinsiyet değişkenine göre anlamlı bir farklılık göstermemektedir ( $\mathrm{p}>$.05).

Tablo 3. Öğretmenlerin Özyeterlilik ve Sınıf Yönetim Becerilerine İlişkin Görüşlerinin Eğitim Durumlarına Göre ANOVA Testi

\begin{tabular}{|c|c|c|c|c|c|c|c|}
\hline & & $\mathrm{N}$ & Ort. & Std. Sapma & $\mathrm{F}$ & $\mathrm{p}$ & $\begin{array}{l}\text { Anlamlı } \\
\text { Farklılık }\end{array}$ \\
\hline \multirow{4}{*}{$\begin{array}{l}\text { Özyeterlilik } \\
\text { Öğrenci } \\
\text { Katılımı }\end{array}$} & Önlisans** & 23 & 7,5652 & 90913 & \multirow{4}{*}{4,130} & \multirow{4}{*}{0,017} & \multirow{4}{*}{$\begin{array}{l}\text { *Önlisans- } \\
\text { Lisans }\end{array}$} \\
\hline & Lisans* & 351 & 6,9395 & 1,09442 & & & \\
\hline & $\begin{array}{l}\text { Yüksek } \\
\text { Lisans }\end{array}$ & 20 & 7,2125 & 79895 & & & \\
\hline & Toplam & 394 & 6,9898 & 1,08074 & & & \\
\hline \multirow{5}{*}{$\begin{array}{l}\text { Özyeterlilik } \\
\text { Sınıf Yönetimi }\end{array}$} & Önlisans & 23 & 7,8424 & 69210 & \multirow{4}{*}{3,521} & \multirow{4}{*}{0,091} & \multirow{7}{*}{$\begin{array}{l}\text { *Önlisans- } \\
\text { Lisans }\end{array}$} \\
\hline & Lisans & 351 & 7,3718 & ,95466 & & & \\
\hline & $\begin{array}{l}\text { Yüksek } \\
\text { Lisans }\end{array}$ & 20 & 7,6688 & 78144 & & & \\
\hline & Toplam & 394 & 7,4143 & 94001 & & & \\
\hline & Önlisans ${ }^{* *}$ & 23 & 7,9457 & 69681 & \multirow{4}{*}{5,296} & \multirow{4}{*}{0,005} & \\
\hline \multirow{3}{*}{$\begin{array}{l}\text { Özyeterlilik } \\
\text { Öğretim } \\
\text { Stratejileri }\end{array}$} & Lisans* & 351 & 7,3543 & 87537 & & & \\
\hline & $\begin{array}{l}\text { Yüksek } \\
\text { Lisans }\end{array}$ & 20 & 7,5000 & 65268 & & & \\
\hline & Toplam & 394 & 7,3963 & ,86602 & & & \multirow{7}{*}{$\begin{array}{l}\text { *Önlisans- } \\
\text { Lisans }\end{array}$} \\
\hline \multirow{6}{*}{$\begin{array}{l}\text { Genel } \\
\text { Özyeterlilik }\end{array}$} & Önlisans ${ }^{* *}$ & 23 & 7,7844 & 69514 & \multirow{4}{*}{5,456} & \multirow{4}{*}{0,005} & \\
\hline & Lisans* & 351 & 7,2219 & ,85325 & & & \\
\hline & $\begin{array}{l}\text { Yüksek } \\
\text { Lisans }\end{array}$ & 20 & 7,4604 & ,63356 & & & \\
\hline & Toplam & 394 & 7,2668 & ,84512 & & & \\
\hline & Önlisans & 23 & 3,6191 & 25523 & \multirow{2}{*}{2,583} & \multirow{2}{*}{0,077} & \\
\hline & Lisans & 351 & 3,4430 & 37022 & & & \\
\hline
\end{tabular}




\begin{tabular}{|c|c|c|c|c|}
\hline $\begin{array}{l}\text { Genel Sinıf } \\
\text { Yönetimi }\end{array}$ & $\begin{array}{l}\text { Yüksek } \\
\text { Lisans }\end{array}$ & 20 & 3,4800 & 34653 \\
\hline Becerileri & Toplam & 394 & 3,4551 & ,36504 \\
\hline
\end{tabular}

Tablo 3'te araştırmaya katılan öğretmenlerin özyeterlilik ve sınıf yönetim becerilerine ilişkin görüşlerinin eğitim durumlarına göre farklılık analizi Tek Yönlü ANOVA Testi ile analiz edilmiştir. Yapılan analiz sonucunda öğretmenlerin özyeterlilik düzeylerine ilişkin görüşlerinin eğitim durumlarına göre farklılık gösterdiği tespit edilmiştir $(p>0,05)$. Söz konusu farklılıkların hangi eğitim grupları arasındaki farklılıktan meydana geldiğini tespit etmek için yapılan post-hoc (Tukey testi) analizine göre, önlisans mezunu olan öğretmenlerin öğrenci katılımına yönelik özyeterlilik düzeyleri, öğretim stratejilerine yönelik özyeterlilik düzeyleri ve genel özyeterlilik düzeylerinin lisans mezunu olan öğretmenlere göre daha yüksek düzeyde olduğu tespit edilmiştir.

Tablo 4. Öğretmenlerin Özyeterlilik ve Sınıf Yönetim Becerilerine İlişkin Görüşlerinin Bulunduğu Okuldaki Toplam Hizmet Süresine Göre ANOVA Testi

\begin{tabular}{|c|c|c|c|c|c|c|c|}
\hline & & $\mathrm{N}$ & Ort. & Std. Sapma & $\mathrm{F}$ & $\mathrm{p}$ & $\begin{array}{l}\text { Anlamlı } \\
\text { Farklılık }\end{array}$ \\
\hline \multirow{7}{*}{$\begin{array}{l}\text { Özyeterlilik } \\
\text { Öğrenci } \\
\text { Katılımı }\end{array}$} & $\begin{array}{l}1 \text { Yildan } \\
\text { az }\end{array}$ & 85 & 6,9603 & ,99780 & \multirow{7}{*}{0,926} & \multirow{7}{*}{0,464} & \\
\hline & $1-5 Y_{11}$ & 239 & 6,9833 & 1,17455 & & & \\
\hline & 6-10 Yil & 46 & 6,8913 & 73956 & & & \\
\hline & 11-15 Yil & 17 & 7,5074 & 79974 & & & \\
\hline & $16-20 \mathrm{Y}_{11}$ & 5 & 7,1000 & 1,29120 & & & \\
\hline & $21-25 Y_{11}$ & 2 & 6,6250 & ,35355 & & & \\
\hline & Toplam & 394 & 6,9898 & 1,08074 & & & \\
\hline \multirow{7}{*}{$\begin{array}{l}\text { Özyeterlilik } \\
\text { Sınıf Yönetimi }\end{array}$} & $\begin{array}{l}1 \text { Yildan } \\
\text { az }\end{array}$ & 85 & 7,2412 & 1,01510 & \multirow{7}{*}{1,427} & \multirow{7}{*}{0,214} & \\
\hline & 1-5 $Y_{11}$ & 239 & 7,4283 & ,96384 & & & \\
\hline & 6-10 Y1l & 46 & 7,5027 & 70931 & & & \\
\hline & $11-15 Y_{11}$ & 17 & 7,8382 & 72855 & & & \\
\hline & $16-20 Y_{11}$ & 5 & 7,5500 & 69372 & & & \\
\hline & $21-25 Y_{11}$ & 2 & 7,1250 & ,53033 & & & \\
\hline & Toplam & 394 & 7,4143 & ,94001 & & & \\
\hline \multirow{7}{*}{$\begin{array}{l}\text { Özyeterlilik } \\
\text { Ögrretim } \\
\text { Stratejileri }\end{array}$} & $\begin{array}{l}1 \text { Yildan } \\
\text { az }\end{array}$ & 85 & 7,3912 & ,88384 & \multirow{7}{*}{0,924} & \multirow{7}{*}{0,466} & \\
\hline & 1-5 Yil & 239 & 7,4012 & 90319 & & & \\
\hline & 6-10 Y Yl & 46 & 7,2609 & 64325 & & & \\
\hline & $11-15 Y_{11}$ & 17 & 7,7353 & 79042 & & & \\
\hline & $16-20 Y_{11}$ & 5 & 7,5500 & 83198 & & & \\
\hline & $21-25 Y_{11}$ & 2 & 6,8750 & 35355 & & & \\
\hline & Toplam & 394 & 7,3963 & ,86602 & & & \\
\hline \multirow{5}{*}{$\begin{array}{l}\text { Genel } \\
\text { Özyeterlilik }\end{array}$} & $\begin{array}{l}1 \text { Yildan } \\
\text { az }\end{array}$ & 85 & 7,1975 & 88941 & \multirow{5}{*}{1,125} & \multirow{5}{*}{0,346} & \\
\hline & $1-5 Y_{1} l$ & 239 & 7,2709 & ,87962 & & & \\
\hline & 6-10 Y 11 & 46 & 7,2183 & ,58697 & & & \\
\hline & $11-15 Y_{11}$ & 17 & 7,6936 & 66421 & & & \\
\hline & $16-20 Y_{11}$ & 5 & 7,4000 & ,91506 & & & \\
\hline
\end{tabular}




\begin{tabular}{|c|c|c|c|c|c|c|c|c|}
\hline \multirow{10}{*}{$\begin{array}{l}\text { Genel } \\
\text { Yönetimi } \\
\text { Becerileri }\end{array}$} & \multirow{10}{*}{ Sinif } & $21-25 Y_{11}$ & 2 & 6,8750 & ,41248 & \multirow{10}{*}{2,547} & & \multirow{10}{*}{$\begin{array}{l}{ }^{*} 11-15 \text { yll-1 } \\
\text { yıldan az }\end{array}$} \\
\hline & & Toplam & 394 & 7,2668 & 84512 & & \multirow{9}{*}{0,028} & \\
\hline & & $\begin{array}{l}1 \text { Yildan } \\
\mathrm{az}^{*}\end{array}$ & 85 & 3,3675 & 39490 & & & \\
\hline & & 1-5 Y 11 & 239 & 3,4626 & 36389 & & & \\
\hline & & 6-10 Y 11 & 46 & 3,4757 & 31215 & & & \\
\hline & & $11-15$ & 17 & 36800 & 27857 & & & \\
\hline & & $Y_{1} 1^{* *}$ & & & & & & \\
\hline & & 16-20 Yil & 5 & 3,6000 & 24166 & & & \\
\hline & & $21-25 Y_{1} 1$ & 2 & 3,5400 & 48083 & & & \\
\hline & & Toplam & 394 & 3,4551 & ,36504 & & & \\
\hline
\end{tabular}

Tablo 4'te araştırmaya katılan öğretmenlerin özyeterlilik ve sınıf yönetim becerilerine ilişkin görüşlerinin bulunduğu okuldaki toplam hizmet süresine göre farklılık analizi Tek Yönlü ANOVA Testi ile analiz edilmiştir. Yapılan analiz sonucunda öğretmenlerin sınıf yönetim becerilerine ilişkin görüşlerinin bulunduğu okuldaki toplam hizmet süresine göre farklılık gösterdiği tespit edilmiştir ( $p>0,05)$. Söz konusu farklılığın hangi toplam hizmet süresi grupları arasındaki farklılıktan meydana geldiğini belirlemek için gerçekleştirilen post-hoc (Tukey testi) analizi neticesinde, 11-15 yıl aralığında bulunduğu okulda görev yapan öğretmenlerin 1 yıldan az görev yapan öğretmenlere göre sınıf yönetim becerileri düzeylerinin daha yüksek düzeyde olduğu tespit edilmiştir.

Tablo 5. Öğretmenlerin Özyeterlilik ve Sınıf Yönetim Becerilerine İlişkin Görüşlerinin Toplam Mesleki Kıdem Sürelerine Göre ANOVA Testi

\begin{tabular}{|c|c|c|c|c|c|c|c|}
\hline & & $\mathrm{N}$ & Ort. & Std. Sapma & F & $\mathrm{p}$ & $\begin{array}{l}\text { Anlamlı } \\
\text { Farklılık }\end{array}$ \\
\hline \multirow{7}{*}{$\begin{array}{l}\text { Özyeterlilik } \\
\text { Öğrenci } \\
\text { Katılımı }\end{array}$} & 1 Yildan az & 26 & 6,6442 & ,92850 & \multirow{8}{*}{0,734} & \multirow{8}{*}{0,622} & \multirow{22}{*}{$\begin{array}{l}{ }^{*} 11-15 \text { Y } 11-1 \\
\text { yıldan az }\end{array}$} \\
\hline & 1-5 Yil & 153 & 6,9935 & 1,02485 & & & \\
\hline & 6-10 Yil & 116 & 6,9698 & 1,28860 & & & \\
\hline & $11-15 Y_{11}$ & 61 & 7,1066 & 94891 & & & \\
\hline & $16-20 Y_{11}$ & 20 & 7,1813 & ,85885 & & & \\
\hline & $21-25 Y_{11}$ & 13 & 7,0769 & 78319 & & & \\
\hline & $\begin{array}{l}26 \text { Yil ve } \\
\text { üzeri }\end{array}$ & 5 & 6,7250 & 1,25437 & & & \\
\hline \multirow{9}{*}{$\begin{array}{l}\text { Özyeterlilik } \\
\text { Sinıf Yönetimi }\end{array}$} & Toplam & 394 & 6,9898 & 1,08074 & & & \\
\hline & 1 Yıldan az & 26 & 6,8750 & 1,02042 & \multirow{8}{*}{2,407} & \multirow{8}{*}{0,027} & \\
\hline & 1-5 Yil & 153 & 7,3979 & 98325 & & & \\
\hline & 6-10 Y 11 & 116 & 7,4526 & 85205 & & & \\
\hline & $11-15 Y_{11}{ }^{* *}$ & 61 & 7,5369 & 91837 & & & \\
\hline & $16-20 Y_{11}$ & 20 & 7,6000 & 61184 & & & \\
\hline & 21-25 Yil & 13 & 7,7212 & ,94256 & & & \\
\hline & $\begin{array}{l}26 \text { Yil ve } \\
\text { üzeri }\end{array}$ & 5 & 6,8000 & 1,57520 & & & \\
\hline & Toplam & 394 & 7,4143 & 94001 & & & \\
\hline \multirow{6}{*}{$\begin{array}{l}\text { Özyeterlilik } \\
\text { Ögrretim } \\
\text { Stratejileri }\end{array}$} & 1 Yildan az & 26 & 7,1827 & 99199 & \multirow{6}{*}{0,773} & \multirow{6}{*}{0,592} & \\
\hline & 1-5 Yll & 153 & 7,4371 & 90413 & & & \\
\hline & 6-10 Y1l & 116 & 7,3125 & 82018 & & & \\
\hline & 11-15 Yil & 61 & 7,4406 & ,87696 & & & \\
\hline & $16-20 Y_{11}$ & 20 & 7,5250 & 64838 & & & \\
\hline & $21-25 Y_{11}$ & 13 & 7,6154 & ,89335 & & & \\
\hline
\end{tabular}




\begin{tabular}{|c|c|c|c|c|c|c|}
\hline & $\begin{array}{l}26 \text { Yil ve } \\
\text { üzeri }\end{array}$ & 5 & 7,5750 & ,57690 & \multirow{10}{*}{1,285} & \multirow{10}{*}{0,263} \\
\hline & Toplam & 394 & 7,3963 & ,86602 & & \\
\hline \multirow{8}{*}{$\begin{array}{l}\text { Genel } \\
\text { Özyeterlilik }\end{array}$} & 1 Yildan az & 26 & 6,9006 & ,88444 & & \\
\hline & 1-5 Y1l & 153 & 7,2761 & 88044 & & \\
\hline & 6-10 Y1l & 116 & 7,2450 & 82094 & & \\
\hline & 11-15 Yil & 61 & 7,3613 & 82841 & & \\
\hline & $16-20 Y_{11}$ & 20 & 7,4354 & 60569 & & \\
\hline & $21-25 Y_{11}$ & 13 & 7,4712 & 80335 & & \\
\hline & $\begin{array}{l}26 \text { Yil ve } \\
\text { üzeri }\end{array}$ & 5 & 7,0333 & 1,05261 & & \\
\hline & Toplam & 394 & 7,2668 & ,84512 & & \\
\hline \multirow{8}{*}{$\begin{array}{l}\text { Genel Sınıf } \\
\text { Yönetimi } \\
\text { Becerileri }\end{array}$} & 1 Yildan az & 26 & 3,3569 & 41041 & \multirow{8}{*}{1,798} & \multirow{8}{*}{0,098} \\
\hline & 1-5 Yil & 153 & 3,4376 & 39112 & & \\
\hline & 6-10 Y 11 & 116 & 3,4362 & 35758 & & \\
\hline & 11-15 Yil & 61 & 3,5259 & 29807 & & \\
\hline & $16-20 Y_{11}$ & 20 & 3,5520 & 33330 & & \\
\hline & 21-25 Yil & 13 & 3,6246 & 21759 & & \\
\hline & $\begin{array}{l}26 \quad Y_{1} \text { ve } \\
\text { üzeri }\end{array}$ & 5 & 3,2480 & 43945 & & \\
\hline & Toplam & 394 & 3,4551 & ,36504 & & \\
\hline
\end{tabular}

Tablo 5'te araştırmaya katılan öğretmenlerin özyeterlilik ve sınıf yönetim becerilerine ilişkin görüşlerinin toplam hizmet süresine göre farklılık analizi Tek Yönlü ANOVA Testi ile analiz edilmiştir. Yapılan analiz sonucunda öğretmenlerin özyeterlilik ölçeği sınıf yönetim alt boyutuna ilişkin görüşlerinin bulunduğu toplam hizmet süresine göre farklılık gösterdiği tespit edilmiştir $(p<0,05)$. Söz konusu farklılığın hangi hizmet süresi grupları arasındaki farklılıktan meydana geldiğini belirlemek için gerçekleştirilen post-hoc (Tukey testi) analizi neticesinde, 11-15 yıl aralığında toplam hizmet süresi olan öğretmenlerin 1 yıldan az görev yapan öğretmenlere göre özyeterlilik ölçeği sınıf yönetim alt boyutuna ilişkin görüşlerinin daha yüksek düzeyde olduğu tespit edilmiştir.

Tablo 6. Öğretmenlerin Özyeterlilik ve Sınıf Yönetim Becerilerine İlişkin Görüşlerinin Branşlarına Göre ANOVA Testi

\begin{tabular}{|c|c|c|c|c|c|c|c|}
\hline & & $\mathrm{N}$ & Ort. & $\begin{array}{l}\text { Std. } \\
\text { Sapma }\end{array}$ & $\mathrm{F}$ & $\mathrm{p}$ & $\begin{array}{l}\text { Anlamlı } \\
\text { Farklılık }\end{array}$ \\
\hline \multirow{13}{*}{$\begin{array}{l}\text { Özyeterlilik } \\
\text { Öğrenci } \\
\text { Katılımı }\end{array}$} & Sınıf Öğretmeni & 171 & 7,0797 & 1,15226 & \multirow{13}{*}{1,443} & \multirow{13}{*}{0,151} & \\
\hline & Türkçe & 25 & 6,7250 & 76376 & & & \\
\hline & Matematik & 31 & 6,5161 & 1,02558 & & & \\
\hline & Fen Bilimleri & 25 & 6,9800 & 76944 & & & \\
\hline & Sosyal Bilgiler & 20 & 6,9750 & ,91999 & & & \\
\hline & İngilizce & 28 & 7,0938 & 1,00613 & & & \\
\hline & $\begin{array}{l}\text { Din Kültürü ve } \\
\text { Ahlak Bilgisi }\end{array}$ & 28 & 6,9643 & ,99934 & & & \\
\hline & Görsel Sanatlar & 6 & 6,0000 & 1,73385 & & & \\
\hline & Müzik & 7 & 6,9821 & 1,12368 & & & \\
\hline & Beden Eğitimi & 6 & 7,1458 & 1,06189 & & & \\
\hline & Teknoloji Tasarım & 6 & 7,1458 & 49634 & & & \\
\hline & Diğer & 41 & 7,1951 & 1,17661 & & & \\
\hline & Toplam & 394 & 6,9898 & 1,08074 & & & \\
\hline
\end{tabular}




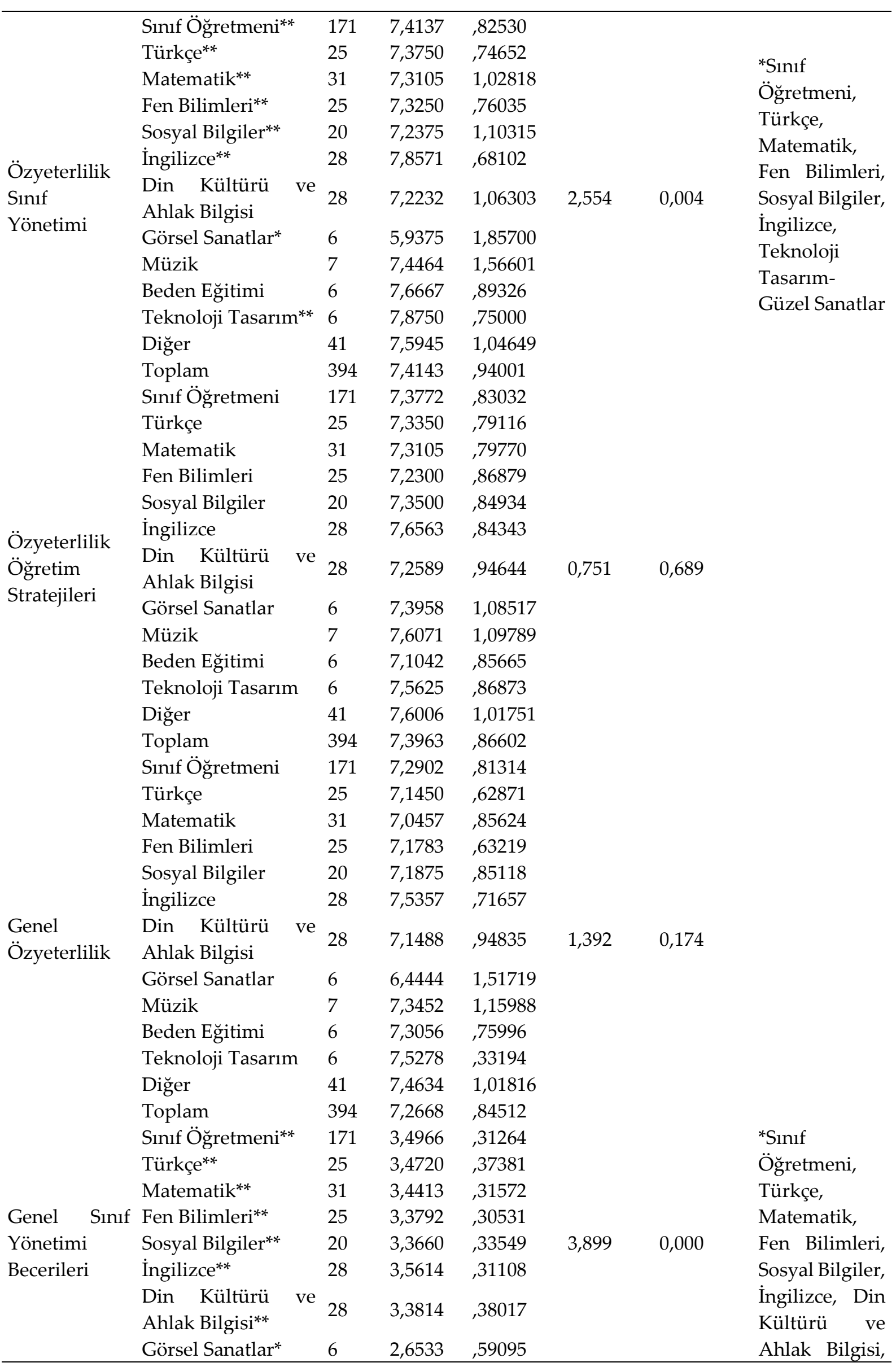




\begin{tabular}{lllll} 
Müzik** $^{* *}$ & 7 & 3,3371 &, 61703 & Beden Eğimi, \\
Beden Eğitimi** $^{* *}$ & 6 & 3,3000 &, 40140 & Teknoloji \\
Teknoloji Tasarım** $^{*}$ & 6 & 3,4933 &, 43353 & Tasarım- \\
Diğer & 41 & 3,5044 &, 43173 & Güzel Sanatlar \\
Toplam & 394 & 3,4551 &, 36504 & \\
\hline
\end{tabular}

Tablo 6'da araştırmaya katılan öğretmenlerin özyeterlilik ve sınıf yönetim becerilerine ilişkin görüşlerinin branşlarına göre farklılık analizi Tek Yönlü ANOVA Testi ile analiz edilmiştir. Yapılan analiz sonucunda öğretmenlerin özyeterlilik ölçeği sınıf yönetim alt boyutuna ilişkin görüşleri ile genel sınıf yönetim becerileri düzeylerinin branşlarına göre farklılık gösterdiği tespit edilmiştir ( $>>0,05)$. Söz konusu farklılığın hangi branşlar arasındaki farklılıktan meydana geldiğini belirlemek için gerçekleştirilen post-hoc (Tukey testi) analizi neticesinde, görsel sanatlar branşında eğitim veren öğretmenlerin özyeterlilik ölçeği sınıf yönetim alt boyutuna ilişkin görüşleri ile genel sınıf yönetim becerileri düzeylerinin diğer tüm branştaki öğretmenlere göre daha düşük düzeyde olduğu tespit edilmiştir.

Tablo 7. Öğretmenlerin Özyeterlilik ve Sınıf Yönetim Becerilerine İlişkin Görüşlerinin Hizmetiçi Eğitim Alma Durumlarına Göre Bağımsız Grup t Testi

\begin{tabular}{lllllll}
\hline & $\begin{array}{l}\text { Hizmeti } \\
\text { çi }\end{array}$ & $\mathrm{N}$ & Ort. & Std. Sapma & $\mathrm{t}$ & $\mathrm{p}$ \\
\hline $\begin{array}{l}\text { Özyeterlilik } \\
\text { Öğrenci }\end{array}$ & Evet & 213 & 7,0258 &, 95471 & & \\
Katılımı & Hayır & 181 & 6,9475 & 1,21378 & 0,378 & 0,474 \\
Özyeterlilik & Evet & 213 & 7,4806 &, 93067 & & \\
$\begin{array}{l}\text { Sınıf Yönetimi } \\
\text { Hayır }\end{array}$ & 181 & 7,3363 &, 94752 & 0,138 & 0,129 \\
$\begin{array}{l}\text { Özyeterlilik } \\
\text { Oggretim }\end{array}$ & Evet & 213 & 7,4789 &, 87179 & & \\
$\begin{array}{l}\text { Stratejileri } \\
\text { Genel }\end{array}$ & Hayır & 181 & 7,2990 &, 85132 & 0,204 & 0,040 \\
$\begin{array}{l}\text { Özyeterlilik } \\
\text { Genel Sınıt }\end{array}$ & Hayır & 1813 & 7,3284 &, 82981 & & \\
$\begin{array}{l}\text { Yönetimi } \\
\text { Becerileri }\end{array}$ & Hayıt & 213 & 3,1943 &, 85943 & 0,110 & 0,116 \\
\hline
\end{tabular}

Tablo 7'de öğretmenlerin özyeterlilik ve sınıf yönetim becerilerine ilişkin görüşlerinin sınıf yönetimi ile ilgili hizmetiçi eğitim alma durumlarına göre farklılık analizi Bağımsız grup t testi ile analiz edilmiştir. Yapılan analiz sonucunda sınıf yönetimi ile ilgili hizmetiçi eğitim alan öğretmenlerin öğretim stratejilerine yönelik özyeterlilik düzeylerinin sınıf yönetimi ile ilgili hizmetiçi almayanlara göre daha yüksek düzeyde olduğu tespit edilmiştir $(p<0,05)$.

Tablo 8. Özyeterlilik ve Sınıf Yönetimi Arasındaki İlişkiye Yönelik Pearson Korelasyon Analizi

\begin{tabular}{lllllll}
\hline & & $\begin{array}{l}\text { Özyeterlilik } \\
\text { Öğrenci } \\
\text { Katılımı }\end{array}$ & $\begin{array}{l}\text { Özyeterlilik } \\
\text { Sinıf } \\
\text { Yönetimi }\end{array}$ & $\begin{array}{l}\text { Özyeterlilik } \\
\text { Ögretim } \\
\text { Stratejileri }\end{array}$ & $\begin{array}{l}\text { Genel } \\
\text { Özyeterlilik }\end{array}$ & $\begin{array}{l}\text { Genel Sınıf } \\
\text { Yönetimi } \\
\text { Becerileri }\end{array}$ \\
\hline $\begin{array}{l}\text { Özyeterlilik } \\
\text { Öğrenci } \\
\text { Katılımı }\end{array}$ & Pea.Cor. & 1 & & & \\
& Sig. (2-tailed) & & & & \\
& Pea.Cor. &, $639^{* *}$ & 1 & & & \\
\hline
\end{tabular}




\begin{tabular}{|c|c|c|c|c|c|}
\hline $\begin{array}{l}\text { Özyeterlilik } \\
\text { Sinıf } \\
\text { Yönetimi }\end{array}$ & Sig. (2-tailed) & ,000 & & & \\
\hline Özyeterlilik & Pea.Cor. & $640^{* *}$ &, $695^{* *}$ & 1 & \\
\hline $\begin{array}{l}\text { Öğretim } \\
\text { Stratejileri }\end{array}$ & Sig. (2-tailed) & ,000 & ,000 & & \\
\hline Genel & Pea.Cor. &, $881^{* *}$ &, $880^{* *}$ & $872^{* *}$ & 1 \\
\hline Özyeterlilik & Sig. (2-tailed) & ,000 & ,000 & ,000 & \\
\hline Genel Sinif & Pea.Cor. & $465^{* *}$ &, $550^{* *}$ &, $532^{* *}$ &, $584^{* *}$ \\
\hline $\begin{array}{l}\text { Yönetimi } \\
\text { Becerileri }\end{array}$ & Sig. (2-tailed) & ,000 & ,000 & ,000 & ,000 \\
\hline
\end{tabular}

Tablo 8 'de öğretmenlerin özyeterlilik düzeyleri ile sınıf yönetim düzeyleri arasındaki ilişki Pearson korelasyon analizi ile incelenmiştir. Analiz neticesinde sınıf yönetim düzeyleri ile özyeterlilik düzeyleri arasında pozitif yönlü ve orta düzeyli ilişki olduğu tespit edilmiştir ( $\mathrm{p}<$ 0,05; Pea.Cor: $r=0,584$ ). Bu çerçevede öğretmenlerin özyeterlilik düzeyleri arttıkça sinıf yönetim düzeyleri de artış göstermektedir.

\section{Sonuç ve Tartışma}

Araştırda elde edilen bulgular neticesinde ulaşılan sonuçlar şu şekildedir:

Veri analizi sonucunda öğretmenlerin sınıf yönetimi becerilerinin cinsiyet, bulunduğu okuldaki toplam hizmet süresi ve branş değişkenlerine göre istatistiksel olarak anlamlı bir farklılık gösterdiği tespit edilmiştir. Öğretmenlerin sınıf yönetimi becerileri eğitim düzeyi, mesleki kıdem ve alınan hizmetiçi eğitim değişkenlerine göre anlamlı bir farklılık göstermemektedir. Öğretmenlerin özyeterlikleri eğitim düzeyi, mesleki kıdem, branş ve alınan hizmet içi eğitim değişkenlerine göre anlamlı bir farklılık göstermektedir. Öğretmenlerin özyeterlikleri cinsiyet, bulunduğu okuldaki toplam hizmet süresi ve değişkenlerine göre anlamlı bir farklılık göstermemektedir. Öğretmenlerin özyeterlilikleri ile sınıf yönetimi becerileri arasında pozitif yönlü ve orta düzeyli ilişki olduğu tespit edilmiştir.

Araştırmaya katılan öğretmenlerin sınıf yönetim beceri düzeylerinin cinsiyet değişkenine göre kadın öğretmenler lehine anlamlı düzeyde farklılaştığı tespit edilmiştir. Öğretmenlerin cinsiyetinin sınıf yönetim becerileri bağlamında ulaşılan bu bulgunun alan yazınla paralellik gösteren ve göstermeyen çalışmaların olduğu görülmektedir. Vatansever-Bayraktar ve Kendirci (2020) tarafından yapılan araştırma sonucunda sınıf öğretmenlerinin sınıf yönetim becerileri cinsiyet değişkenine göre genel toplamda ve öğrenme öğretme süreci, iletişim, davranış yönetimi alt boyutlarında kadın sınıf öğretmenleri lehine istatistiksel olarak anlamlı bir farklılık göstermektedir. Vatansever-Bayraktar ve Kendirci (2020) tarafından yapılan araştırma sonucu mevcut araştırmayı desteklemektedir. Aküzüm ve Özdemir-Gültekin (2017)'nin araştırma sonunda öğretmenlerin cinsiyetlerine göre sınıf yönetimi becerilerine ilişkin görüşleri arasında öğrenme-öğretme süreci, zaman yönetimi ve davranış yönetimi boyutlarında kadın öğretmenlerin lehine anlamlı bir farklılık görülmüştür. Sınıfın fiziksel düzeni ve motivasyon boyutlarında ise grupların görüşleri arasında istatistiksel olarak anlamlı bir farklılık görülmemiştir. Aküzüm ve Özdemir-Gültekin (2017)'nin araştırma sonucu mevcut araştırma ile hem benzerlik hem de farklılık göstermektedir. Cinsiyetin sınıf yönetim becerileri açısından belirleyici olduğunu saptayan birçok araştırma mevcuttur (Güner, 2010; İlgar, 2007; Uslu ve Avcı, 2016; Yalçınkaya ve Tonbul, 2002). Güneş (2021) tarafından yapılan araştırma sonucunda ise özel ve resmi okullarda görev yapan öğretmenlerin cinsiyetleri ile 
sinıf yönetim becerileri arasında anlamlı bir farklılık olmadı̆̆ görülmüştür. Özer (2013) ise aday öğretmenlerin sınıf yönetimi yeterliliklerine ilişkin algılarını incelediği araştırmasında aday öğretmenlerin sınıf yönetimi yeterliliklerinde cinsiyet değişkenine göre anlamlı farklılık görülmemiştir. Babaoğlan ve Korkut (2010)'nın araştımasında sınıf öğretmenlerinin sınıf yönetimi beceri algılarının "plan-program etkinlikleri ve fiziksel düzen", "öğretmen-öğrenci ilişkisinin düzenlenmesi ve zaman kullanımı" ve "sınıf içi etkileşim ve davranış düzenlemeleri” boyutlarında, cinsiyete göre farklılık göstermediği tespit edilmiştir. Güneş (2021)' in; Özer (2013)'in; Babaoğlan ve Korkut (2010)'nın araştırma sonuçları mevcut araştırma sonucu ile farklılık göstermektedir.

Araştırmaya katılan öğretmenlerin öz yeterlik inançları cinsiyet değişkenine göre istatisitksel olarak anlamlı bir farklılık göstermemektedir. Aslan ve Kalkan (2018) tarafından yapılan araştırma sonucunda da öğretmenlerin özyeterlik algılarının cinsiyet değişkeni açısından anlamlı bir farklılık göstermediği belirlenmiştir. Saracaloğlu, Aldan-Karademir, Dinçer ve Dedebali (2017) tarafından yapılan araştırma sonucunda da öğretmenlerin özyeterlikleri kadın ve erkek öğretmenler arasında öğrenci katılımını sağlama, öğretim stratejilerini kullanma ve sınıf yönetimi alt boyutları açısından istatistiksel olarak anlamlı fark olmadığı bulunmuştur. Uysal ve Kösemen (2013) tarafından yapılan araştırma sonucunda da pedagojik formasyon programı öğrencilerinin genel öz-yeterlikleri cinsiyete göre anlamlı bir farklılık göstermemektedir. Aslan ve Kalkan (2018), Uysal ve Kösemen (2013), Saracaloğlu, AldanKarademir, Dinçer ve Dedebali (2017) tarafından yapılan araştırmalar mevcut araştırmayı desteklemektedir. Ayrıca cinsiyetin öz yeterlik inancı açısından belirleyici olmadığını gösteren ve mevcut araştırmayı destekleyen pek çok araştırma mevcuttur. (Aksoy, 2000; AldanKarademir, 2013; Benzer, 2011; Buluç ve Demir (2015); Hashemi ve Ghanizadeh, 2011; Saracaloğlu ve Aydoğdu, 2012; Şahin-Taşkın ve Hacıömeroğlu, 2010; Urhan, 2013; Uysal, 2013; Yorgancı ve Bozgeyikli, 2016; Ekici, 2008; Penrose, Perry ve Ball, 2007). Aldan-Karademir (2013) tarafından yapılan araştırma sonucunda öğretmen adaylarının öğretmen özyeterlikleri, cinsiyet değişkenine göre anlamlı farklılık gösterdiği tespit edilmiştir. Cinsiyet değişkeni açısından öğretmen adaylarının öğretmen öz-yeterlikleri Öğretmen Öz-yeterlik Ölçeği'nin sadece "Sınıf Yönetimi" alt ölçeğinde anlamlı olarak farklılaştığ1; erkek öğretmen adaylarının öğretmen öz-yeterliklerinin, kız öğretmen adaylarının öğretmen özyeterliklerinden daha yüksek olduğu sonucuna ulaşılmıştır. Aldan- Karademir (2013)'in araştırması mevcut araştırma sonucundan farklılık göstermektedir.

Öğretmenlerin özyeterlikleri eğitim düzeyi değişkenine göre anlamlı bir farklılık göstermektedir. Buna göre önlisans mezunu olan öğretmenlerin öğrenci katılımına yönelik özyeterlilik düzeyleri, öğretim stratejilerine yönelik özyeterlilik düzeyleri ve genel özyeterlilik düzeylerinin lisans mezunu olan öğretmenlere göre daha yüksek düzeyde olduğu tespit edilmiştir. Karahan ve Uyanık-Balat (2011) tarafından yapılan araştırma sonucunda ise eğitimcilerin öz-yeterlik algılarının eğitim düzeyi değişkenlere göre anlamlı şekilde farklılaşmadığı bulunmuştur. Parlar, Cansoy ve Türkoğlu (2016) tarafından yapılan araştırmada öğretmen adaylarının özyeterlik algılarının eğitim düzeylerine göre farklılaşmadığı görülmüştür. Karahan ve Uyanık-Balat (2011); Parlar, Cansoy ve Türkoğlu (2016) tarafından yapılan araştırmalar mevcut araştırma sonucundan farklılık göstermektedir.

Öğretmenlerin sınıf yönetimi becerileri mesleki kıdem değişkenine göre anlamlı bir farklılık göstermemektedir. Güneş (2021) tarafından yapılan araştırma sonucunda özel ve resmi okullarda görev yapan öğretmenlerin sınıf yönetimi becerilerinin mesleki kıdem değişkenine 
göre anlamlı bir farklılık göstermediği sonucuna ulaşılmıştır. Güneş (2021)'in araştırması mevcut araştırma sonucunu destekler niteliktedir. Aküzüm ve Özdemir- Gültekin (2017)'nin araştırmasında mesleki kıdem değişkenine göre, öğretmenlerin sınıf yönetimi becerilerine ilişkin görüşleri sınıfın fiziksel düzeni, öğrenme-öğretme süreci, davranış yönetimi ve motivasyon becerileri boyutlarında anlamlı farklılık olduğu görülmüştür. 11-20 yıl mesleki kıdem grubundaki öğretmenler diğer kıdem gruplarına göre sınıf yönetimi becerileri konusunda kendilerini daha az yeterli görürken, mesleki kıdemi daha çok olan (21 yıl ve üzeri) öğretmenlerin ise sınıf yönetimi becerileri konusunda kendilerini en yüksek düzeyde yeterli gören öğretmen grubu olduğu anlaşılmıştır. Aküzüm ve Özdemir- Gültekin (2017)'nin araştırması mevcut araştırma sonucu ile farklılık göstermektedir.

Öğretmenlerin özyeterlikleri mesleki kıdem değişkenine göre anlamlı bir farklılık göstermektedir. 11-15 yıl aralığında toplam hizmet süresi olan öğretmenlerin 1 yıldan az görev yapan öğretmenlere göre özyeterlilik ölçeği sınıf yönetim alt boyutuna ilişkin görüşlerinin daha yüksek düzeyde olduğu tespit edilmiştir. Aslan ve Kalkan (2018) tarafından yapılan araştırma sonucunda da öğretmenlerin özyeterlik algılarının mesleki kıdem değişkeni açısından anlamlı bir farklılık gösterdiği belirlenmiştir. Kıdemi 5 yıl ve daha az olan öğretmenler ile kıdemi 16- 20 yıl olan öğretmenlerin özyeterlik algılarında hem "öğrenci katılımı" ve hem de "sınıf yönetimi" boyutlarında, kıdemi 16- 20 yıl olan öğretmenler lehine anlamlı bir fark vardır. Mesleki kıdemi daha çok olan öğretmenlerin özyeterlik algıalrı daha yüksektir. Aslan ve Kalkan (2018) tarafindan yapılan araştırma mevcut araştırayı desteklemektedir. Saracaloğlu, Karasakaloğlu ve Gencel (2010) tarafından yapılan araştırma sonucunda öğretmenlerin özyeterlik ölçeği "öğretim stratejilerinde yeterlik" ve "sinıf yönetiminde yeterlik" alt ölçeklerinden elde ettikleri puanlarının, öğretmenlerin meslekteki kıdemlerine göre anlamlı düzeyde farklılaşmadığı; öğretmenlerin "öğrenci katılımını sağlama" alt ölçeği puanları ile ölçeğin toplamından elde etmiş oldukları puanların anlamlı olarak farklılaştığı anlaşılmaktadır. 16-20 yıl arası mesleki kıdeme sahip öğretmenler, öğrenci katılımını sağlama ve toplam puanlarda en yüksek puanı elde etmişlerdir. Saracaloğlu, Karasakaloğlu ve Gencel (2010)'in araştırması mevcut araştırma ile hem benzer hem farklı yönler içermektedir. Karahan ve Uyanık- Balat (2011) tarafından yapılan araştırmada ise özel eğitim okullarında çalışan eğitimcilerin öz-yeterlik algılarının meslekte çalışma süresi değişkenlere göre anlamlı şekilde farklılaşmadı̆̆ı bulunmuştur. Saracaloğlu, AldanKarademir, Dinçer ve Dedebali (2017) tarafından yapılan araştırma sonucunda öğretmenlerin özyeterlik düzeylerinin farklı kıdeme sahip öğretmenler arasında istatistiksel açıdan anlamlı bir fark oluşturmadığı saptanmıştır. Penrose, Perry ve Ball (2007) tarafından yapılan araştırmada, öğretmenlerin öz yeterlik algılarının kıdem değişkenine göre anlamlı bir şekilde farklılaşmadığı tespit edilmiştir. Karahan ve Uyanık- Balat (2011)'ın, Saracaloğlu, AldanKarademir, Dinçer ve Dedebali (2017)'nin; Penrose, Perry ve Ball (2007)'ın araştırmaları mevcut araştırma sonucu ile farklılık göstermektedir.

Veri analizi sonucunda öğretmenlerin sinıf yönetimi becerilerinin görev yaptığı okuldaki toplam hizmet süresi değişkenine göre istatistiksel olarak anlamlı bir farklılık gösterdiği tespit edilmiştir. 11-15 yıl aralığında bulunduğu okulda görev yapan öğretmenlerin 1 yıldan az görev yapan öğretmenlere göre sinıf yönetim becerileri daha yüksek düzeydedir. Uç (2013) tarafından yapılan araştırmada öğretmenlerin sınıf yönetimi becerileri çalışılan kurumdaki mesleki kıdeme göre 20 yıl ve üzeri grubunun lehine anlamlı farklılıklar göstermiştir. Uç (2013) tarafından yapılan araştırma mevcut araştırma sonucu ile nispeten benzerlik 
göstermektedir. Öğretmenlerin özyeterlikleri bulunduğu okuldaki toplam hizmet süresi değişkenine göre anlamlı bir farklılık göstermemektedir.

Veri analizi sonucunda öğretmenlerin sınıf yönetimi becerilerinin ve özyeterliklerinin branş değişkenine göre istatistiksel olarak anlamlı bir farklılık gösterdiği tespit edilmiştir. Görsel sanatlar branşında eğitim veren öğretmenlerin özyeterlilik ölçeği sınıf yönetim alt boyutuna ilişkin görüşleri ile genel sınıf yönetim becerileri düzeylerinin diğer tüm branştaki öğretmenlere göre daha düşük düzeyde olduğu tespit edilmiştir. Aslan ve Kalkan (2018) tarafından yapılan araştırma sonucunda ise öğretmenlerin özyeterlik algılarının branş değişkenleri açısından anlamlı bir farklılık göstermediği belirlenmiştir. Öğretmenlerin özyeterlik algıları branş değişkenine göre, hem ölçeğin alt boyutlarında hem de ölçeğin genelinde anlamlı fark göstermemektedir. Bununla birlikte, Matematik ve Fen Bilimleri branşından olan öğretmenlerin "öğrenci katılımı" ve "öğretim stratejileri" boyutlarında; Güzel Sanatlar ve Spor branşından olan öğretmenlerin ise "sınıf yönetimi" boyutunda kendilerini daha yeterli gördükleri anlaşılmaktadır. Saracaloğlu, Aldan-Karademir, Dinçer ve Dedebali (2017) tarafından yapılan araştırma sonucunda Sınıf, Fen ve Teknoloji ile Türkçe öğretmenleri arasında öğretmen özyeterlik puanlarına ilişkin sadece öğrenci katılımını sağlama alt boyutunda Sınıf öğretmenlerinin lehine istatistiksel açıdan anlamlı fark olduğu tespit edilmiştir. Nitekim Başer, Günhan ve Yavuz (2005), Savran ve Çakıroğlu (2003), Zengin-Kapıcı (2003) tarafından yapılan araştırmalarda da öğretmenlerin özyeterlik algılarının branşlarından bağımsız olduğu saptanmıştır.

Veri analizi sonucunda öğretmenlerin özyeterlilikleri ile sınıf yönetimi becerileri arasında pozitif yönlü ve orta düzeyli ilişki olduğu tespit edilmiştir. Öğretmenlerin özyeterlilik düzeyleri arttıkça sınıf yönetimi becerileri de artmaktadır. Kayabaşı, Yeniceli, Ataman, Şahin ve Nacar (2017) tarafından, Ankara ilindeki ortaokul öğretmenlerinin sınıf yönetimi becerilerine yönelik algıları ile öz yeterlilik inançları arasındaki ilişkiyi incelemek amacıyla yapılan çalışmada sınıf yönetimi ölçeğinin alt boyutlarından uyarma davranışları ve beklenti ve kurallara uymaile öz yeterlik ölçeğinin dersi planlama, dersi uygulama ve değerlendirme alt boyutları arasında pozitif bir ilişkinin olduğu ve ilgi çekme davranışı, etkileşimsel davranışlar, ilgiyi sürdürme ve sorun çözme davranışları, demokratik davranışlar, beklenti ve kurallara uyma davranışları ile öz yeterlik ölçeğinin alt boyutların olan dersi planlamauygulama-değerlendirme arasında zayıf düzeyde pozitif bir ilişki olduğu görülmüştür. Ögrretmenlerin sınıf yönetimi becerileri ile öz yeterlik inançları arasında anlamlı bir ilişki gözlenmektedir. Parlar, Cansoy ve Türkoğlu (2016) tarafından yapılan araştırmada, öğretmen adaylarının özyeterlik algıları ile sınıf yönetimi stratejileri algıları arasında orta düzeyde ve pozitif yönde anlamlı bir ilişki bulunmuştur. Babaoğlan ve Korkut (2010) tarafından yapılan araştırma sonucunda sınıf öğretmenlerinin öz yeterlik inançları ile sınıf yönetimi becerilerinin tüm boyutları arasında orta düzeyde olumlu ve anlamlı bir ilişkinin olduğu görülmüştür. Kayabaşı, Yeniceli, Ataman, Şahin ve Nacar (2017); Parlar, Cansoy ve Türkoğlu (2016); Babaoğlan ve Korkut (2010) tarafından yapılan araştırmalar mevcut araştırma sonucunu desteklemektedir.

\section{Öneriler}

-Araştırmada elde edilen bulgular neticiesinde kadın öğretmenlerin sınıf yönetimi becerilerinin erkek öğretmenlere göre daha yüksek olduğu görülmüştür. Erkek öğretmenlerin 
sınıf yönetimi becerilerini arttırıcı yönde eğitim seminerleri ve hizmet içi eğitim desteği verilebilir.

-Bulunduğu okulda daha uzun süre görev yapan öğretmenlerin sınıf yönetimi becerileri daha yüksek çıkmıştır. Bu hususta okulda yeni görev yapmaya başlayan öğretmenlerin öncelikli olarak sınıflarındaki öğrencilerin bireysel özelliklerini iyi tanımaları, öğrenciden beklentilerini açıklaması ve onların velileri ile toplantılar yapıp beklentilerini söylemesi sınıf yönetimini dolaylı da olsa etkileyebilir. Ayrıca okuldaki kıdemli öğretmenler bu yeni başlayan öğretmenlere sınıf yönetimi le ilgili deneyimlerini paylaşabilirler.

-Sınıf yönetimiyle ilgili yapılan bilimsel çalışmalar, bu bilimsel çalışmaların sonuçları, öğretmenlerle paylaşılabilir ve öğretmenler mevcut durumdan haberdar edilebilir.

-Yöneticiler, öğretmenlerin özyeterliliklerini arttırıcı eğitimler, seminerler vb. faaliyetlerle sınıf yönetim becerilerinin artmasını sağlayarak eğitim kalitesini yükseltebilirler.

- Öğretmenler sınıf yönetim becerileri konularında uzman kişiler tarafından bilgilendirilebilir.

-Öğretmenlerin öz yeterlik inançlarının ve sınıf yönetim becerilerini geliştirdiği iki değişkenin de birbirini desteklediği bilimsel çalışmalarla desteklenerek öğretmenlerle paylaşılabilir ve öğretmenlerin bu konularda yeterli düzeye gelmeleri sağlanabilir.

-Ayrıca bir platform oluşturularak öğretmenlerin bilgi alışverişinde bulunmaları sağlanabilir. -MEB merkez ve ilçe teşkilatları öz yeterlik inancını zayıflatması muhtemel olan bölge ve okullarda çalışan öğretmenlere ek destekler sağlamalıdır.

-Araştırmacılar, öğretmenlerin özyeterlilikleri ve sınıf yönetimleri ile ilgili bağımlı bağımsız değişken noktasında başka kavramlarla ilişkilendirerek ve daha geniş örneklemlerle çalışmalar yapabilir.

-Alan yazın çalışmalarında daha çok nicel araştırma yöntemlerinin kullanıldığı görülmüştür. Sınıf yönetim becerileri ve öz yeterlik inancı ile ilgili nitel araştırma yöntemlerinin benimsendiği farklı çalışmalar yapılabilir.

-Bu çalışma İstanbul ilindeki ilkokul ve ortaokul öğretmenlerine uygulanmıştır. Farklı illerde bulunan farklı düzeydeki okullardaki branş ve sinıf öğretmenlerine ve yükseköğretim okullarındaki akademisyenlere de uygulanarak elde edilen sonuçlar farklı kademelerdeki öğretmenlerle karşılaştırılabilir.

\section{Katkı Oranı Beyanı}

Bu çalışmaya birinci yazar \%50 oranında, ikinci yazar \%50 oranında katkı sağlamıştır.

\section{Çatışma Beyanı}

Bu çalışmada herhangi bir potansiyel çıkar çatışması bulunmamaktadır.

\section{KAYNAKÇA}

Akbaş, A. ve Çelikkaleli, Ö. (2006). Sınıf öğretmeni adaylarının fen öğretimi özyeterlik inançlarının cinsiyet, öğrenim türü ve üniversitelerine göre incelenmesi, Mersin Üniversitesi Eğitim Fakültesi Dergisi, 2(1), 98-110. 
Aksoy, N. (2000). Sınıf içi disiplin sorunlarını azaltmada izlenebilecek temel yaklaşımlar, Ĕ̆itim Araştırmaları. 2, 5-9.

Aküzüm, C. ve Özdemir-Gültekin, S. (2017). Sınıf öğretmenlerinin iletişim becerileri ile sınıf yönetimi becerileri arasındaki ilişkinin incelenmesi. Electronic Journal of Education Sciences, 6 (12) , 88-107.

Aldan-Karademir, Ç. (2013). Öğretmen adaylarının sorgulama ve eleştirel düşünme becerilerinin öğretmen öz yeterlik düzeyine etkisi, Yayınlanmamış Doktora Tezi, Adnan Menderes Üniversitesi Sosyal Bilimler Enstitüsü, Aydın.

Alzubi, Z. H. (2013). Classroom management problems among teacher students training at hashemite university, European Journal of Business and Social Sciences, 2(3), 140-149.

Ashton, P. (1984). Teacher efficacy: a motivational paradigm for effective teacher education, Journal of Teacher Education, 35(5), 28-32.

Aslan, M. ve Kalkan, H. (2018). Öğretmenlerin özyeterlik algılarının analizi. Bingöl Üniversitesi Sosyal Bilimler Enstitüsü Dergisi, 8(16), 477-493.

Aydın, A. (1998). Sinıf yönetimi, Ankara: Anı Yayınevi.

Aydın, T. (2020). Sosyal bilgiler öğretmenlerinin mesleki tükenmişlik düzeylerinin ve öğretmen özyeterlik inançlarının incelenmesi, Yayınlanmamış Yüksek Lisans Tezi, Van Yüzüncü Yıl Üniversitesi, Eğitim Bilimleri Enstitüsü, Van.

Babaoğlan, E. ve Korkut, K. (2010). Sınıf öğretmenlerinin öz yeterlik inançları ile sınıf yönetimi beceri algıları arasındaki ilişki. İnönü Üniversitesi Ĕ̆itim Fakültesi Dergisi, 11(1), 1-20.

Balc1, A. (2015). Öğretmen ve öğretmen adaylarının eğitim inançları ile özyeterlik inançlarının incelenmesi (Okul öncesi örneği), Yayınlanmamış Yüksek Lisans Tezi, Atatürk Üniversitesi, Eğitim Bilimleri Enstitüsü, Erzurum.

Baltacı, H. (2008). Ilköğretim okullarında görev yapan yöneticilerin bilgisayar tutumları ile özyeterlilikleri arasındaki ilişkinin incelenmesi, Yayınlanmamış Yüksek Lisans Tezi, Yeditepe Üniversitesi, Sosyal Bilimler Enstitüsü, İstanbul.

Bandura, A. (1977). Social learning theory, englewood cliffs, New Jersey: Prentice-Hall.

Bandura, A. (1988). Self-Efficacy conception of anxiety, Anxiety Research, 1(2): 77-98.

Bandura, A. (1994). Self-efficacy. In V. S. Ramachaudran, Bahavior, Encyclopedia of Human, 4, 71-81.

Başar, H. (1999). Sınıf yönetimi, İstanbul: MEB Yayınları. 
Başer, N., Günhan, B. C. ve Yavuz, G. (2005). Ilköğretim öğretmen adaylarmın ve öğretmenlerin öğretmen yeterlik algılarının karşılaştııllması üzerine bir araştırma. Denizli: XIV. Ulusal Eğitim Bilimleri Kongresi.

Bayraktar, F. (2020). Okul yöneticilerinin özyeterlikleri ile politik becerileri arasındaki ilişki, Yayınlanmamış Yüksek Lisans Tezi, Pamukkale Üniversitesi, Eğitim Bilimleri Enstitüsü, Denizli.

Benzer, F. (2011). İlköğretim ve orta öğretim kurumlarında görev yapan öğretmenlerin öz yeterlik algılarının analizi, Yayınlanmamış Yüksek Lisans Tezi, Selçuk Üniversitesi Eğitim Bilimleri Enstitüsü, Konya.

Buluç, B. ve Demir, S. (2015). İlk ve ortaokul öğretmenlerinin öz yeterlilik algıları ile iş doyumları arasındaki ilişki, Ahi Evran Üniversitesi Kırşehir Eğitim Fakültesi Dergisi, 16(1), 289-308.

Celep, C. (2000). Sinıf yönetimi ve disiplini, Ankara: Nobel Yayınları.

Conner, T. (2016). Relationships: the key to student engagement, International Journal of Education and Learning, 5(1), 13-22.

Çakmak, M. (2005). Sınıfortamı ve grup etkileşimi, Ankara: Nobel Yayın Dağıtım

Çapa, Y., Çakıroğlu, J. ve Sarıkaya, H. (2005). Öğretmen Özyeterlik Ölçeği Türkçe uyarlamasının geçerlik ve güvenirlik çalışması. Ĕ̆ilim ve Bilim, 10(117), 74-81.

Çelik, V. (2012). Sını yönetimi, Ankara: Nobel Yayınevi.

Çolak, G. (2019). Öğretmenlerin özyeterlik alğları ile iş stresleri arasındaki ilişkinin incelenmesi, Yayınlanmamış Yüksek Lisans Tezi, Kastamonu Üniversitesi, Sosyal Bilimler Enstitüsü, Kastamonu.

Demirtaş, H. (2011). Sınıf yönetiminin temelleri, Hüseyin Kıran, Kazım Çelik (Ed.), Etkili sınıf yönetimi içinde (s.1-30), Ankara: Anı Yayıncılık.

Erden, M. (2003). Sınıf Yönetimi, İstanbul: Alkım Yayınevi.

Ekici, G. (2008). Sınıf yönetimi dersinin öğretmen adaylarının öğretmen öz-yeterlik alg1 düzeyine etkisi. Hacettepe Üniversitesi Eğitim Fakültesi Dergisi, 35 (35), 98-110.

Ganyaupfu, E. M. (2013). Teaching Methods and Students, Academic Performance. International Journal of Humanities and Social Science Invention, 2(9), 29-35.

Gibson, S. and Dembo, M. H. (1984). Teacher efficacy: a construct Geçerliation, Journal of Educational Psychology, 76(4), 569-582. 
Goddard, R. D., Hoy, W. K. and Hoy, A. W. (2004). Collective efficacy beliefs: Theoretical developments, empirical evidence, and future directions. Educational Researcher, 33(3), 313.

Gündoğan, A. ve Koçak, S. (2017). Öğretmen adaylarının okul iklimi algıları ile akademik özyeterlik inançları arasındaki ilişkinin incelenmesi. Sakarya University Journal of Education, 7(3), 639-657.

Güneş, A. (2021). Özel ve resmi okullarda görev yapan öğretmenlerin tükenmişlik düzeyleri ve sınıf yönetim becerileri arasındaki ilişki. Mehmet Akif Ersoy Üniversitesi Eğitim Fakültesi Dergisi, (58), 290-311.

Güner, N. (2010). Kaynaştırma uygulamaları yapılan sınıflarda çalışan öğretmenlerin sınıf yönetimi bilgi düzeyleri ile önleyici sını yönetimi eğitim programının öğretmenlerin sınıf yönetimlerine etkisinin incelenmesi, Yayımlanmamış Doktora Tezi, Ankara Üniversitesi Eğitim Bilimleri Enstitüsü, Ankara.

Hashemi, M. R. and Ghanizadeh, A. (2011). Emotional intelligence and self-efficacy: a case of Iranian EFL university students. International Journal of Linguistics, 3(1), 1-16.

İlgar, L. (2007). İlköğretim öğretmenlerinin sınıf yönetimi becerileri üzerine bir araştırma, Yayımlanmamış Doktora Tezi, İstanbul Üniversitesi Sosyal Bilimler Enstitüsü, İstanbul.

Kanık, Ü. S. (2019). Sinıf öğretmenlerinin özyeterlik inançlarn ile mesleğe yönelik tutumlarının karşılaştırılmalı olarak incelenmesi, Yayınlanmamış Yüksek Lisans Tezi, Burdur Mehmet Akif Ersoy Üniversitesi, Eğitim Bilimleri Enstitüsü, Burdur.

Karahan, Ş. ve Uyanık-Balat, G. (2011). Özel eğitim okullarında çalışan eğitimcilerin özyeterlik algılarının ve tükenmişlik düzeylerinin incelenmesi. Pamukkale Üniversitesi Ĕ̆itim Fakültesi Dergisi, 29 (29) , 1-14.

Karasar, N. (2015). Sosyal bilimlerde araştırma teknikleri, Ankara: Nobel Yayın Dağıtım.

Kayabaşı, Y., Yeniceli, E., Ataman, E., Şahin, S. ve Nacar, N. (2017). Ortaokul öğretmenlerinin sınıf yönetimi becerileri ile özyeterlik inançlari arasındaki ilişki: Ankara ili örneği. Kuramsal Eğitimbilim Dergisi [Journal of Theoretical Educational Science], 10(2), 298-319.

Konan, E. (2018). Kamu ve özel eğitim kurumlarında çalışan ortaöğretim fen bilimleri öğretmenlerinin iş doyumları ve öz yeterlik düzeylerinin çeşitli değişkenler açısından incelenmesi, Yayınlanmamış Yüksek Lisans Tezi, Marmara Üniversitesi, Eğitim Bilimleri Enstitüsü, İstanbul.

Koç, F. ve Sak R. (2016). Okul öncesi öğretmenlerinin okul öncesi eğitim programındaki etkinliklere yönelik öz-yeterlik inançlarının incelenmesi. Uludă̆ Üniversitesi Eğitim Fakültesi Dergisi, 30(1), 43-71. 
Kurt, T. (2012). Öğretmenlerin öz yeterlik ve kolektif yeterlik algıları. Journal of Turkish Educational Sciences, 10(2), 195-227.

Lee, B., Cawthon, S. and Dawson, K. (2012). Elementary and secondary teacher self- efficacy for teaching and pedagogical conceptual change in drama based professional development program. Teaching and Teacher Education. 30. 84-98.

Martin, N. K. and Shoho, A. R. (2000). Teacher experience, training, and age: the influence of teacher characteristics on classroom management style, Paper presented at the Annual Conference of the Southwest Educational Research Association.

Özdemir, C. (2015). Sınıf öğretmeni adaylarının ilkokuma ve yazma öğretimine ilişkin öz yeterlik inançlarının belirlenmesi, Yayınlanmamış Yüksek Lisans Tezi, Karadeniz Teknik Üniversitesi, Trabzon.

Özdemir, S. M. (2008). Sınıf öğretmeni adaylarının öğretim sürecine ilişkin öz-yeterlik inançlarının çeşitli değişkenler açısından incelenmesi, Kuram ve Uygulamada Ĕ̆itim Yönetimi, 54, 277-306.

Özdemir, S. M. (2011). Sınıf ortamını etkileyen sınıf içi ve dışı etkenler, Ankara: Pegem Akademi.

Özer, F. (2013). Aday öğretmenlerin sınıf yönetimi yeterliklerine ilişkin algıları, Yayımlanmamış Yüksek Lisans Tezi, Fırat Üniversitesi Eğitim Bilimleri Enstitüsü, Elazığ.

Parlar, H., Cansoy, R. ve Türkoğlu, M. (2016). Öğretmen adaylarının özyeterlikleri ile sınıf yönetim stratejileri arasındaki ilişki. Yükseköğretim Dergisi, 6 (1), 28-39.

Pajares, F. (2002). Gender and perceived self-efficacy in self-regulated learning, Theory Into Practice, 41(2), 116-125.

Penrose, F., Perry, C. and Ball, I. (2007). Emotional intelligence and teacher self efficacy: the contribution of teacher status and length of experience, Issues in Educational Research, 17(1), 107-126.

Rahimi, M. and Karkami, F. H. (2015). The role of teachers' classroom discipline in their teaching effectiveness and students' language learning motivation and achievement, Iranian Journal of Language Teaching Research, 3(1), 57-82.

Ritter, J., Boone, W. and Rubba, P. (2001). Development of on instrument to assess prospective elementary teacher self-efficacy beliefs about equitable science teaching and learning (SEBEST), Journal of Science Teacher Education, 12(3), 175-198.

Roberts, J.K., Henson, R.K., Tharp, B.Z. and Moreno, N. (2001). An examination of change in teacher self-efficacy beliefs in science education based on the duration of in-service activities, Journal of Science Teacher Education, 12(3), 199-213. 
Ross, J. and Bruce, C. (2007). Professional development effects on teacher efficacy, results of randomized field trial, The Journal of Educational Research, 101(1), 50-60.

Saracaloğlu, A., Karasakaloğlu, N. ve Gencel, İ . (2010). Türkçe öğretmenlerinin özyeterlik düzeylerinin çeşitli değişkenlere göre incelenmesi. Elektronik Sosyal Bilimler Dergisi, 9 (33), 265-283.

Saracaloğlu, A. S. ve Aydoğdu, B. (2012). Fen ve teknoloji öğretmenlerinin kişilerarasi özyeterlik inançlarının bazı değişkenler açısından incelenmesi. International Journal of New Trends in Arts, Sports \& Science Education (IJTASE) ISSN: 2146-9466, 1(1), 21-35.

Saracaloğlu, A.S., Aldan-Karademir, Ç., Dinçer, B. ve Dedebali, N.C., (2017). Öğretmenlerin öğretme stilleri, özyeterlik ve iş doyumlarının belirlenmesi, Education Sciences (NWSAES), 12(1),58-85, DOI: 10.12739/NWSA.2017.12.1.1C0669.

Savran, A. and Çakıroğlu, J., (2003). Difference between elemantary and secondary preservice science teachers' perceived efficacy beliefs and their classroom manegement beliefs. The Turkish Online Journal of Educational Technology, 2 (4), 15-20.

Schriver, M. (1993). A comparison of middle and junior high science teachers, levels of efficacy, and knowledge of developmentally appropriate curriculum and instruction, Presented at the Annual Meeting of the National Association for Research in Science Teaching. Atlanta

Schriver, M. and Czerniak, C. M. (1999). A comparison of middle and junior high science teachers levels of efficacy and knowledge of developmentally appropriate curriculum and instruction, Journal of Science Teacher Education, 10(1), 21-42.

Senemoğlu, N. (2005). Gelişim öğrenme ve öğretim: Kuramdan uygulamaya. Ankara: Gazi Kitabevi.

Shinn, Y. H. (1997). Teaching strategies, their use and effectiveness as perceived by teachers of agriculture, a national study (PhD Thesis), Ames, Iowa: Iowa State University.

Şahin-Taşkın, Ç. ve Haciömeroğlu, G. (2010). Öğretmen özyeterlik inanç ölçeğinin türkçeye uyarlanması ve sınıf öğretmeni adaylarının özyeterlik inançları. Dokuz Eylül Üniversitesi Buca Eğitim Fakültesi Dergisi, (27), 63-75. Retrieved from https://dergipark.org.tr/en/pub/deubefd/issue/25435/268375

Telef, B. B. (2011). Öğretmenlerin öz-yeterlikleri, iş doyumları, yaşam doyumları ve tükenmişliklerinin incelenmesi, İlköğretim Online, 10(1), 91-108.

Tschannen-Moran, M., Hoy, A. W. and Hoy, W. K. (1998). Teacher efficacy: Its meaning and measure. Review of educational research, 68(2), 202-248.

Tschannen-Moran, M. and Woolfolk-Hoy, A. (2001). Teacher efficacy: Capturing an elusive construct. Teaching and Teacher Education. 17 (7), 783-805. 
Türk, N. (2009). Beden eğitimi ve spor öğretmenlerinin mesleklerine ilişkin öz yeterlik düzeylerinin incelenmesi (Nevşehir ili örneği). Yayımlanmamış Yüksek Lisans Tezi. Niğde Üniversitesi. Sosyal Bilimler Enstitüsü. Beden Eğitimi Spor ABD., Niğde.

Uç, H. (2013). İlkokul öğretmenlerinin sınıf yönetimi becerileri ile örgüt kültürü arasındaki ilişki, Yayımlanmamış Yüksek Lisans Tezi, Yeditepe Üniversitesi Sosyal Bilimler Enstitüsü, İstanbul.

Urhan, İ. (2013). Türkçe öğretmeni adaylarının yansıtıcı düşünme ile öğretmen öz yeterlik algısı arasındaki ilişkinin incelenmesi: Niğde Üniversitesi örneği. Yayınlanmamış Yüksek Lisans Tezi, Niğde Üniversitesi Ĕ̆itim Bilimleri Enstitüsü, Niğde.

Uslu, T. ve Avcı, M. (2016). Eğitim fakültesi öğretim elemanlarının sınıf yönetimi becerilerinin bazı değişkenler açısından incelenmesi. Erzincan Üniversitesi Eğitim Fakültesi Dergisi, 18 (1), 611-637

Uysal, İ. (2013). Akademisyenlerin genel öz-yeterlik inançları: AİBÜ Eğitim Fakültesi örneği, Trakya Üniversitesi Eğitim Fakültesi Dergisi, 3 (2), 144-151. Retrieved from https://dergipark.org.tr/en/pub/trkefd/issue/21474/230174

Uysal, K. ve Kösemen, S. (2013). Öğretmen adaylarının genel öz yeterlilik inançlarının incelenmesi, Ĕ̆itim ve Öğretim Araştırmaları Dergisi, 2(2), 217-226.

Vatansever Bayraktar, H. (2015). Sınıf yönetiminde öğrenci motivasyonu ve motivasyonu etkileyen etmenler. Electronic Turkish Studies, 10(3). 1079-1100.

Vatansever Bayraktar, H. (2016). Examination of the self-efficacy of primary school teacher candidates towards first reading-writing education, Higher Education Studies, 6(4), 119130.

Vatansever Bayraktar, H. \& Dogan, M. C. (2017). Investigation of primary school teachers' perception of discipline types they use for classroom management. Higher Education Studies, 7(1), 30-45.

Vatansever Bayraktar, H., Kadığlu Ateş, H., ve Afat, N. (2019). An analysis on the relationship between primary school teachers' self-efficacy beliefs and attitudes towards gifted education, International Journal of Eurasia Social Sciences 10(38), 1099-1124.

Vatansever Bayraktar, H. ve Kendirci, M. (2020). Sınıf öğretmenlerinin sinıf yönetimi becerilerinin incelenmesi, Akademik Sosyal Araştırmalar Dergisi, Yı1: 7, Sayı: 46, 207-232, Doi Number:http://dx.doi.org/10.29228/SOBIDER.43244

Woolfolk, A. E. and Hoy, W. K. (1990). Prospective teachers' sense of efficacy and beliefs about control. Journal of Educational Psychology, 82(1), 81-91

Yalçınkaya, M. ve Tombul, Y. (2002). İlköğretim okulu sınıf öğretmenlerinin sınıf yönetimi becerilerine ilişkin alg1 ve gözlemler. Ege Eğitim Dergisi. 1 (2), 96-108. 
Yaşar, S. (2008). Classroom management approaches of primary school teachers. Master Thesis. Middle East Technical University The Department of Educational Sciences, Ankara.

Yaz, A. H. (2018). Ortaokul öğretmenlerinin özyeterlik algıları ile öğretmen liderliği davranışları arasındaki ilişkinin incelenmesi, Yayınlanmamış Yüksek Lisans Tezi, Kastamonu Üniversitesi, Sosyal Bilimler Enstitüsü, Kastamonu.

Yılmaz, İ. (2010). Türkçe öğretmen adaylarının özel alan ve öz yeterlik algıları, Yayımlanmamış Yüksek Lisans Tezi, Atatürk Üniversitesi Sosyal Bilimler Enstitüsü, Erzurum.

Yorgancı, A. E., ve Bozgeyikli, H. (2016). Sınıf öğretmenlerinin kişilerarası özyeterlilik algılarıyla örgütsel güven algılarının incelenmesi, OPUS, 6(6), 57-51.

Zengin-Kapıcı, U., (2003). İlköğretim öğretmenlerinin öz-yeterlik algıları ve sınıf-içi iletişim örüntüleri. Yayımlanmamış Yüksek Lisans Tezi. Dokuz Eylül Üniversitesi, Eğitim Bilimleri Enstitüsü. İzmir. 